\title{
BAYBURT CİVİL PEYNİRINIIN BAZI KİMYASAL, BİYOKİMYASAL VE MİKROBİYOLOJİK ÖZELLİKLERİ İLE MİNERAL VE AĞIR METAL İÇERÍKLERİ
}

\author{
Ayla Arslaner ${ }^{1 *}$, Mehmet Ali Salik ${ }^{2}$ \\ ${ }^{1}$ Bayburt Üniversitesi, Mühendislik Fakültesi, Gıda Mühendisliği Bölümü, Bayburt, Türkiye \\ ${ }^{2}$ Atatürk Üniversitesi, Fen Bilimleri Enstitüsü Gıda Mühendisliği Anabilim Dalı, Erzurum, Türkiye
}

Geliş / Received: 18.01.2020; Kabul / Accepted: 03.04.2020; Online bask1 / Published online: 26.04.2020

Arslaner, A., Salık, M.A. (2020). Bayburt civil peynirinin bazı kimyasal, biyokimyasal ve mikrobiyolojik özellikleri ile mineral ve ağır metal içerikleri. GID A (2020) 45(3) 433-447 doi: 10.15237/gida.GD19159

Arslaner, A., Salkk, M.A. (2020). Some chemical, biochemical, microbiological properties, mineral and heavy metal contents of Bayburt civil cheese. GIDA (2020) 45(3) 433447 doi: 10.15237/gida.GD19159

\section{ÖZ}

Piyasadan temin edilen 20 adet Bayburt Civil peynir örneğinde; $\mathrm{pH}$, asitlik, kurumadde, yağ, protein, kül, tuz oranlant sirasiyla, 5.36-6.07; \%0.21-1.25; \%41.92-57.85; \%0.5-26.0; 20.9-35.54; \%3.48-16.0 ve \%1.51-15.43 aralığında belirlenmiştir. Örneklerin toplam azot, suda çözünen azot, triklorasetik asitte çözünen azot değerleri, olgunlaşma dereceleri ve lipoliz oranları sırasıyla; \%3.28-5.57; \%0.19-3.33; \%0.02-0.69; \%4.38-71.2 ve 1.93-12.33 ADV (Asitlik Derecesi Değeri) aralığında bulunmuştur. Araşturma sonuçlant, incelenen Bayburt Civil peynir örneklerinin zengin mineral bileşimi yanı sıra, ağır metal içeriği bakımından herhangi bir sağlık riski taşımadığını; ancak kimyasal kompozisyon, olgunlaşma ölçütleri ve mikrobiyal kalite açısından standart özelliklere sahip olmadığını göstermiştir. Coğrafi İşaret potansiyeli taşıyan bu peynirin orijinal özelliklerinin korunarak kalitesinin geliştirilmesi, kırsal kalkınma yanında halk sağlı̆̆ açısından önem arz etmektedir.

Anahtar kelimeler: Türkiye'nin peynirleri, Bayburt Civil peynir, peynir özellikleri, mineral, yöresel peynir

\section{SOME CHEMICAL, BIOCHEMICAL, MICROBIOLOGICAL PROPERTIES, MINERAL AND HEAVY METAL CONTENTS OF BAYBURT CIVIL CHEESE}

\section{ABSTRACT}

The $\mathrm{pH}$, acidity, dry matter, fat, protein, ash, and salt ratios of 20 Bayburt Civil cheese samples were obtained from market were determined as 5.36 to $6.07,0.21$ to $1.25 \%, 41.92$ to $57.85 \%, 0.5$ to $26.0 \%$, 20.9 to $35.54 \%, 3.48$ to $16.0 \%$ and, 1.51 to $15.43 \%$, respectively. Total nitrogen, water soluble nitrogen, trichloroacetic acid soluble nitrogen, ripening index and lipolysis rates of the samples were detected between 3.28-5.57\%, 0:19-3:33\%, 0.02-0.69\%, 4.38-71.2\%, and 1.93-12.33 ADV (Acid Degree Value) respectively. The research results showed that Bayburt Civil cheese samples in market did not pose any health risks in terms of heavy metal content as well as rich mineral composition; however, they had no standard in terms of chemical composition, ripening properties and microbial quality. Improving product quality of Bayburt Civil cheese, which has the potential of Geographical Indication, is also important for public health as well as rural development.

Keywords: Cheeses of Turkey, Bayburt Civil cheese, cheese properties, mineral, traditional cheese

${ }^{*}$ Yazışmalardan sorumlu yazar/ Corresponding author

$\triangle$ aylaarslaner@bayburt.edu.tr, $\quad$ ( $\quad$ (+90) 458211 1153-1658

圆 (+90) 4582111173

Ayla Arslaner; ORCID no: 0000-0002-2777-9697

Mehmet Ali Salık; ORCID no: 0000-0003-4727-9830 


\section{GİRİ̧̧}

Ülkemizde coğrafi koşullara, kültürel alışkanlıklara, hayvan tür ve ırklarının farklılığına bağlı olarak alışılagelen yapım teknikleri ile çeşitli yöresel peynirler üretilmektedir. Peynirler; peynir mayas1 (rennet), asit ve 1 sil işlem-asit kombinasyonu ile pıhtılaştırılanlar olmak üzere üç gruba ayrilmaktadır (Fox vd., 2015; Cantürk ve Çakmakçı, 2019). Ayrıca Civil peynir; asit, rennet ve 1 sıl işlemin birlikte kullanıldığı orijinal bir peynir çeşidi olup dördüncü bir grup olarak değerlendirilmektedir (Çakmakç1 vd., 2014; Cantürk ve Çakmakçı, 2019).

Erzurum Civil peyniri 06.02.2009 tarihinde Coğrafi İşaret tescili almış (mahreç) ve üretim alanı Erzurum ili ve ilçelerinin oluşturduğu coğrafi bölge ile sınırlandırılmıştır (TÜRK PATENT, 2009). Civil peynir üretiminde sadece yağsız süt, rennet ve tuz kullanilmakta olup, starter kültür ve kalsiyum klorür $\left(\mathrm{CaC1}_{2}\right)$ gibi herhangi bir katk1 maddesi kullanılmamaktadır (TÜRK PATENT, 2009). Yoğun emek isteyen bir üretim tekniğine sahip olan Erzurum Civil peynirinin üretiminde, yağ1 alınmış süt iki parçaya bölünür. İlk kısım, sütün doğal mikrofloras1 tarafindan asitliği arttırmak için gece boyunca yaklaşı $15-20^{\circ} \mathrm{C}^{\prime} \mathrm{de}$ dinlenmeye birakilır. Daha sonra asitlenmiss süt yağsız sütün ikinci kısmına ilave edilerek asitlik $22^{\circ} \mathrm{SH}^{\prime}$ a ayarlanır. Asitliği ayarlanmış süt $30^{\circ} \mathrm{C}^{\prime} y e$ kadar 1sitılır. Sivı şirden mayası ilave edilerek 1sıtma işlemine devam edilir. Süt içerisinde 52$53^{\circ} \mathrm{C}$ de pıhtı parçacıkları oluşmaya başlayınca karıştırma işlemi ile pıhtı parçacıkları bir araya getirilerek kepçenin etrafına sarılması sağlanır. Bu arada meydana gelen pıhtı, yoğurma ve çekme işlemleri ile tel haline getirilir. Son yıllarda yapılan çalışmalarda $58-60{ }^{\circ} \mathrm{C}$ 'den yüksek sicaklık uygulamasıyla peynirin lifli yapısının bozulduğu ve teleme 1 sitma işleminin $55-60^{\circ} \mathrm{C}$ 'de tamamlandığ1 ifade edilmektedir (Çakmakçı vd., 2014; Gurkan vd., 2018). Ayrica günümüzde işletmelerde üretimde doğal yollarla asitliği artırılmış peyniraltı suyu süte karıştrilarak sütün asitliği ayarlanmaktadır (Cambaztepe vd., 2009; Çakmakçı vd., 2014). Lifli yapı kazandırılan peynirler salamura, kuru tuzlama veya vakum ambalajlama yapilmakta, sade ya da Lor peyniri ile birlikte basılarak olgunlaştırma sırasında spontan olarak küflenen peynirler olmak üzere 5 ayrı çeşit peynir olarak pazarlanmaktadır. Son yıllarda kontrollü küflendirme amaçlı, küf izolasyon ve identifikasyonu sonucu elde edilen toksin oluşturmayan Penicillium roqueforti suşları ile küflü Civil peynir üretimi üzerine araştırmalar yapıldığ1 görülmüştür (Çakmakçı vd., 2012a, b; 2014; 2015; Gürkan vd. 2018). Türkiye'nin Doğu ve Kuzeydoğu kesiminde (Erzurum, Bayburt, Kars, Ardahan, Ağrı, Artvin ve Iğdır gibi) Çeçil peynir, tel peynir, iplik peynir, çekme peynir gibi isimlerle de anılan Civil peynir genellikle küçük aile işletmelerinde üretilmekte iken günümüzde daha çok mandıralar veya küçük süt işletmelerinde üretilmektedir (Arslaner ve Salık, 2017).

Civil peynirin hammaddesi (sütün kimyasal ve mikrobiyolojik kalitesi), üretim metodu (1sil işlem ve süre normları, sütte yağ standardizasyonu, Civil hamuruna uygulanan fiziksel işlemin şekli ve süresi, tuzlama teknikleri) ve muhafaza şartları bölgeler arasında farklilik arz etmekte, bu durum peynirin fiziksel, kimyasal, mikrobiyolojik ve duyusal niteliklerini etkilemektedir. Bayburt Civil peyniri üretiminde kullanılan sütün yağ oranı bakımından standardize edilmemesi ve çoğunlukla yağlı süt kullanılması (Arslaner ve Salık, 2017) ve benzerlerine göre daha ince teller halinde işlenmesi ile farkl11ık göstermektedir

$\mathrm{Bu}$ araştırmada, Bayburt İlinde geleneksel olarak üretilen ve yaygın bir şekilde tüketilen Civil peynir örneklerinin bazı kimyasal, biyokimyasal, mikrobiyolojik özellikleri ile mineral kompozisyonu ve ağır metal içeriklerinin belirlenmesi amaçlanmıştır. Böylece ülkemizin yöresel zenginliklerinden biri olan ve bölge kalkınması açısından önemli potansiyele sahip Civil peyniri ile ilgili bir durum tespiti yapilması ve bu konuda bundan sonra yapılacak araştırmalara katkı sağlaması hedeflenmiştir.

\section{MATERYAL ve YÖNTEM}

\section{Materyal}

Araşturmada kullanılan 20 adet Civil peynir örneği Bayburt merkezinde faaliyet gösteren farklı sattş noktalarından temin edilmiştir. Peynir örneklerinin satış noktalarında, kuru tuzlanmış, ince telli yapıda, nispeten sarımsı beyaz renkte 
olduğu, yaklaşı 1-2 kg'llk poşetlerde vakumlama yapılmadan depolandığ1 gözlenmiştir. Peynir örnekleri 500 g'llk steril numune poşetlerine alınmış ve en kısa sürede soğuk zincirle laboratuvara getirilip $4^{\circ} \mathrm{C}$ de buzdolabinda muhafaza edilmiştir. Örneklerde ilk olarak mikrobiyolojik analizler gerçekleştirilmiş olup, bunu kimyasal ve diğer analizler takip etmiştir.

\section{Yöntem}

Civil peynir örneklerinde baz1 kimyasal, mikrobiyolojik ve biyokimyasal analizler ile ağır metal ve mineral madde analizleri yapılmıştır. Örneklerde analizler 4 paralel olacak şekilde yürütülmüştür.

\section{Kimyasal ve Mikrobiyolojik Analizler}

Peynir örneklerinde; kurumadde ve kül (gravimetrik yöntemle), yağ (Van Gulik bütirometresi kullanılarak Gerber yöntemiyle), protein (mikro-Kjeldahl yöntemiyle belirlenen toplam azot oranlarnnin (TN) 6.38 ile çarpılmasıyla), tuz $\left(\mathrm{AgNO}_{3}\right.$ ile titrasyon yöntemiyle), $\mathrm{pH}$ ve titrasyon asitliği (\% laktik asit olarak) analizleri Kurt vd. (2012) tarafindan verilen metotlara göre yapılmıştır.

Peynir örneklerindeki toplam aerobik mezofilik bakteri sayımı (TAMB) Plate Count Agar (PCA, Merck) (30-32 ${ }^{\circ} \mathrm{C}^{\prime}$ de 48 saat), koliform grubu bakteri sayımı Violet Red Bile Agar (VRBA, Merck) $\left(35-37^{\circ} \mathrm{C}^{\prime}\right.$ de 24 saat), maya ve küf sayımı Potato Dextrose Agar (PDA, Merck) \%10'luk steril tartarik asit çözeltisi ile $\mathrm{pH} 3.5^{\prime}$ e ayarlanarak $\left(25^{\circ} \mathrm{C}\right.$ 'de $3-5$ gün), Escherichia coli sayım Chromocult Tryptone Bile X Glucuronide Agar (CTBXA, Merck) $\left(44^{\circ} \mathrm{C}^{\prime}\right.$ de 24 saat) (Harrigan, 1998; Halkman, 2005); Staphylococcus aureus sayım Baird Parker Agar (BPA, Merck) $\left(37^{\circ} \mathrm{C}^{\prime}\right.$ de 24 saat $)$ (Pichhardt, 2004) kullanılarak belirlenmiştir.

\section{Biyokimyasal Analizler}

Peynir örneklerinde suda çözünen azot (WSN) ve \%12'lik triklorasetik asitte çözünen azot (TCASN) oranları Kuchroo ve Fox (1982) tarafindan verilen metoda göre belirlenmiştir. $\mathrm{Bu}$ amaçla, 10 g peynir örneği tartılmış ve üzerine $40^{\circ} \mathrm{C}^{\prime} \mathrm{de} 40 \mathrm{ml}$ su ilave edilerek Ultra Turrax blender ile 2 dakika homojenize edilmiştir. Karışım $40^{\circ} \mathrm{C}^{\prime}$ deki su banyosunda 1 saat tutulduktan sonra $4^{\circ} \mathrm{C}$ 'de 3000 g'de 30 dakika santrifüj edilmiştir. Santrifüj sonrasi üst kısımdaki yağ tabakası bir spatülle uzaklaşturlarak siv1 kısım Whatman filtre kağıdından (Scleicher \& Schuell 589/2) süzülmüş ve elde edilen filtrat saf su ile 100 ml'ye tamamlanmıştrr. Hazırlanan filtrattan $10 \mathrm{ml}$ alınarak standart mikro-Kjeldahl metodu ile suda çözünen azot miktarı belirlenmiş (IDF, 1993) ve kalan filtrat TCA'da çözünen azot tayini için kullanılmıştır. Olgunlaşma derecesi (OD) ise suda çözünen azotun toplam azota oranlanması ile belirlenmiştir. TCA'da çözünen azot oranının belirlenmesinde, suda çözünen azot tayini için hazırlanan filtrattan $25 \mathrm{ml}$ alınarak, eşit hacimde \%24'lük (w/v) TCA ilave edilerek oda sıcaklığında 2 saat tutulmuştur. Daha sonra karışım Whatman filtre kâğıdından (Scleicher \& Schuell 589/2) süzülerek, filtrat saf su ile 50 ml'ye tamamlanmıştur. Filtrattan $10 \mathrm{ml}$ alınarak, standart mikro-Kjeldahl metodu (IDF, 1993) ile TCA'da çözünen azot miktarı belirlenmiştir.

Peynir örneklerinde lipoliz tayini ise IDF (1991)'ye göre yapılmıştır. Bu amaçla $10 \mathrm{~g}$ peynir örneği lipoliz şişesine tartılmış ve üzerine $10 \mathrm{ml}$ BDI çözeltisi (30 g Triton X-100 ve $70 \mathrm{~g}$ sodyum tetra fosfat'ın 1 litre sudaki solüsyonu) ilave edilerek iyice karıştırılmıştır. Örnekler ara sıra çalkalanmak suretiyle 15-20 dakika süreyle sicak su banyosunda tutulmuştur. Su banyosundan alınan şişeler 1 dakika süreyle Gerber santrifüjünde santrifüjlendikten sonra, yağ fazının berrak bir şekilde şişenin boğaz kısmında toplanmasını sağlamak amaciyla yeteri kadar sulu metil alkol $(1: 1, \mathrm{v} / \mathrm{v})$ ilave edilmiş ve tekrar 1 dakika süreyle santrifüjlenmiştir. Lipoliz şişesinin boğaz kısmında toplanan yağ 1 ml'lik şırınga ile alınarak küçük bir erlene aktarılmış ve tartılmıştır. Tartılan yağın üzerine $5 \mathrm{ml}$ yağ solventi (petrol eteri + n-propanol, $4: 1, \mathrm{v} / \mathrm{v}$ ) ve $2-3$ damla $\% 11^{\prime}$ lik fenolftalein ilave edilerek berrak pembemsi renk oluşuncaya kadar alkolle hazırlanmış $0.02 \mathrm{~N}$ ayarlı $\mathrm{KOH}$ ile titre edilmiştir. Harcanan $\mathrm{KOH}$ miktarı formülde [(Vhörnek (ml) $-\mathrm{Vh}_{\text {kör (ml) }} \times{ }^{\times} \quad 0.02 \times 100$ $\div \quad$ örnek miktarı $(\mathrm{g})]$ yerine yazılarak Asit Derecesi Değeri (ADV: meq KOH/ 100 g yağ) olarak lipoliz düzeyi tespit edilmiştir. 


\section{Mineral ve ağır metal içeriğinin belirlenmesi} Peynir örneklerin mineral kompozisyonu küçük bir modifikasyonla Ataro vd. (2008) tarafindan verilen metoda göre belirlenmiştir. İlk önce peynir örneklerinin kurumadde içerikleri kararlı bir tartıma ulaşıncaya kadar $70^{\circ} \mathrm{C}$ de mikrodalga firinda kurutulmuştur. Kurutulan örneklerden yaklaşı $0.5 \mathrm{~g}$ örnek teflon kaplar içerisine tartularak üzerine hacimce 8:2 oranında karıştırılan nitrik asit (\%65)- perklorik asit (\%70-72) çözeltisinden $10 \mathrm{ml}$ ilave edilmiştir. Örnekler mikrodalga firında (Milestone, Ethos Easy) $200^{\circ} \mathrm{C}$ 'de yakıldıktan sonra ultra saf su ile yıkanarak hacimsel kaplara alınmış ve hacim 25 ml'ye tamamlanmıştır. Bu işlemin ardından 0.45 $\mu \mathrm{m}$ filtre kullanılarak örnekler filtre edilmiştir. Daha sonra örneklerin mineral madde içeriği İndüktif Eşleşmiş Plazma Kütle Spektrometresi (Agilent 7800 ICP-MS) kullanilarak ppb $(\mu \mathrm{g} / \mathrm{kg}$ ) olarak belirlenmiştir. Kurutulmuş peynir örneklerinde sonuçlar; makro mineraller için ppm $(\mathrm{mg} / \mathrm{kg})$, mikro mineraller ile ağır metaller için $\mathrm{ppb}(\mu \mathrm{g} / \mathrm{kg})$ olarak verilmiştir.

\section{İstatistiksel Analizler}

Tüm veriler SPSS 22.0 (SPSS Inc., Chicago, IL, USA) yazılımı kullanılarak istatistiksel açıdan analiz edilmiştir. Varyans analizi (ANOVA) sonucunda önemli çıkan faktörler Duncan çoklu karşılaştırma testi ile \%99 güven düzeyinde değerlendirilmiştir.

\section{BULGULAR ve TARTIŞMA}

Bayburt Civil peyniri örneklerinin fiziksel ve kimyasal özellikleri

Peynir örneklerinin; pH, asitlik, kurumadde, yă̆, protein, kül ve tuz değerleri üzerine örnek değişkeninin etkisi istatistiksel olarak önemli bulunmuştur $(P<0.01)$. Peynir örneklerinde $\mathrm{pH}$ değerlerinin 5.36 ile 6.07 aralığında değişim gösterdiği ve ortalama 5.59 olduğu tespit edilmiştir (Çizelge 1). Dikbaş vd. (2006), Çeçil peynir örneklerinde pH'nin 4.92-5.67; Cambaztepe vd. (2009) Erzurum Civil peynir örneklerinde 5.13-5.19; Yildız vd. (2010), Civil peyniri örneklerinde 4.05-4.92; Çakmakç1 vd. (2012a) ise, küflü Civil peyniri örneklerinde 5.127.93 aralı̆̆ında değiştiğini bildirmişlerdir. Bayburt Civil peyniri örneklerinde belirlenen $\mathrm{pH}$ değerleri
Çakmakçı vd. (2012a) tarafindan bildirilen değerlere yakın, diğer çalışmalara göre nispeten daha yüksektir. Civil peynir örneklerinde; asitlik değerlerinin $\% 0.21-01.25$ arasında değiştiği, ortalama \%0.65 olduğu tespit edilmiştir. $\mathrm{Bu}$ çalışmada elde edilen bulgulara benzer olarak; Bakırc1 ve Andiç (1999), Çeçil peyniri örneklerinde asitlik değerlerinin \%0.12-1.25; Dikbaş vd. (2006), Çeçil peynir örneklerinde $\% 0.32-1.05$, Şengül vd. (2006), Civil peynir örneklerinde \%0.63-2.16 aralığında değiştiğini tespit etmişlerdir. Yapılan başka bir çalışmada ise Civil peynir örneklerinde asitlik değerlerinin $\% 0.33$ ile \%1.38 arasında olduğu bildirilmiştir (Cambaztepe vd., 2009). Araştırmada tespit ettiğimiz asitlik değerleri Yıldız vd. (2010) tarafindan bildirilen değerlerden (\%1.68-3.78) oldukça düşüktür.

Civil peynir örneklerinde kurumadde miktarlarının \%41.92 ile \%57.85 aralığında değiştĭgi ve ortalama $\% 50.73$ olduğu saptanmıştır. Yangılar ve Kızılkaya (2015), Çeçil peynir örneklerinde kurumadde oranlarını \%48.7151.19 aralı̆̆ında değiştiğini ve ortalama \%49.43 olduğunu bildirmişlerdir. Başka bir araştırmada ise Çeçil peynir örneklerinde kurumadde oranlarının \%34.8-59.3 aralı̆̆ında değiştiği ve ortalama \%49.59 olduğu tespit edilmiştir (Dikbaş vd., 2006). Çakmakçı vd. (2012a), bu çalışmada elde edilen bulgulara benzer şekilde, küflü Civil peynir örneklerinde kuru madde miktarını \%42.73-54.79 olarak tespit etmişlerdir.

Bayburt Civil peyniri örneklerinde yağ oranları $\% 0.50-\% 26.0$ arasında değişmiştir. İncelenen örnekler arasinda 12, 13, 15, 17 ve 18 numaralı örnekler ile diğer on beş örnek arasında yağ oranı bakımından büyük oranda farklılıkların olduğu görülmektedir (Çizelge 1). Dikbaş vd. (2006), yağ oranlanın $\% 2.0-14.0$ aralığında; Şengül vd. (2006), \%1.0-7.0; Cambaztepe vd. (2009) \%0.16-0.45; Yildız vd. (2010) \%0.50-5.25, Çakmakçı vd. (2012a) ise \%1.00-6.20 aralığında bulmuşlardır. $\mathrm{Bu}$ çalışmada elde edilen bulgular, Şengül vd. (2006), Cambaztepe vd. (2009), Yıldız vd. (2010) ve Çakmakçı vd. (2012a) tarafindan rapor edilen ortalama değerlerden oldukça yüksektir. İncelenen örneklerde, protein miktarlarının 
$\% 20.90$ ile \%35.54 arasında değiştĭgi ve ortalama \%27.71 olduğu görülmektedir (Çizelge 1). Yıldız vd. (2010) Civil peynir örneklerinde protein değerlerini $\% 28.58$ ile $\% 36.84$ aralı̆̆ında,
Çakmakçı vd. (2012a) \%30.08-43.07; Yang1lar ve Kızıllkaya (2015) ise Çeçil peyniri örneklerinde protein oranlarını \%26.35-27.99 arasinda bulmuşlardır.

Çizelge 1 Bayburt Civil peynir örneklerine ait bazı fiziksel ve kimyasal analiz sonuçları

Table 1 Some physical and chemical analysis results of Bayburt Civil cheese samples

\begin{tabular}{|c|c|c|c|c|c|c|c|}
\hline $\begin{array}{l}\text { Örnekler } \\
\text { Samples }\end{array}$ & $\mathrm{pH}$ & $\begin{array}{l}\text { Asitlik (\%) } \\
\text { Acidity (\%) }\end{array}$ & $\begin{array}{l}\mathrm{KM}(\%) \\
D M(\%)\end{array}$ & $\begin{array}{l}\text { Yağ }(\%) \\
\text { Fat }(\%)\end{array}$ & Protein (\%) & $\begin{array}{l}\text { Kül }(\%) \\
\text { Ash (\%) }\end{array}$ & $\begin{array}{l}\text { Tuz }(\%) \\
\text { Salt }(\%)\end{array}$ \\
\hline 1 & $5.47 \pm 0.00^{1}$ & $0.80 \pm 0.00 \mathrm{cc}$ & $47.74 \pm 1.18^{f}$ & $0.50 \pm 0.00 \%$ & $30.29 \pm 0.32 \mathrm{~cd}$ & $8.79 \pm 0.04 \mathrm{i}$ & $7.90 \pm 0.00^{1}$ \\
\hline 2 & $5.44 \pm 0.01 \mathrm{k}$ & $0.99 \pm 0.02^{\mathrm{b}}$ & $41.92 \pm 0.11^{\mathrm{h}}$ & $5.50 \pm 0.00 \check{s}$ & $20.90 \pm 0.24 \mathrm{~m}$ & $10.54 \pm 0.01 \breve{\mathrm{g}}$ & $10.32 \pm 0.16^{\mathrm{f}}$ \\
\hline 3 & $5.43 \pm 0.01^{1}$ & $0.81 \pm 0.02 \varsigma \varsigma$ & $46.95 \pm 0.09^{f}$ & $6.50 \pm 0.00^{f}$ & $26.46 \pm 0.03 \mathrm{~g}$ & $9.82 \pm 0.02^{\mathrm{h}}$ & $8.77 \pm 0.17 \mathrm{~g}$ \\
\hline 4 & $5.70 \pm 0.01^{\mathrm{e}}$ & $0.52 \pm 0.00 \mathrm{~g}$ & $52.11 \pm 0.21$ çd & $3.50 \pm 0.00^{\mathrm{i}}$ & $31.21 \pm 0.03 \mathrm{cc}$ & $11.03 \pm 0.00 \mathrm{~g}$ & $9.01 \pm 0.17 \mathrm{~g}$ \\
\hline 5 & $5.43 \pm 0.01^{1}$ & $0.78 \pm 0.02$ & $45.19 \pm 0.03 \mathrm{~g}$ & $1.50 \pm 0.00^{\mathrm{n}}$ & $26.03 \pm 0.79 \mathrm{gg} g$ & $12.95 \pm 0.01 \mathrm{c}$ & $12.28 \pm 0.17$ s \\
\hline 6 & $5.44 \pm 0.00^{\mathrm{ik}}$ & $0.70 \pm 0.02^{\mathrm{de}}$ & $54.52 \pm 0.33 c$ & $4.50 \pm 0.00^{1}$ & $29.88 \pm 0.20 \mathrm{de}$ & $16.00 \pm 0.07 \mathrm{a}$ & $15.43 \pm 0.00^{\mathrm{a}}$ \\
\hline 7 & $5.45 \pm 0.01^{\mathrm{i}}$ & $0.67 \pm 0.02^{\mathrm{e}}$ & $50.18 \pm 0.61^{\mathrm{e}}$ & $3.00 \pm 0.00^{1}$ & $31.34 \pm 0.33^{c}$ & $11.45 \pm 0.08^{\mathrm{f}}$ & $10.76 \pm 0.00^{\mathrm{e}}$ \\
\hline 8 & $5.41 \pm 0.00 \mathrm{~m}$ & $0.70 \pm 0.02^{\mathrm{de}}$ & $54.86 \pm 0.61 \mathrm{bc}$ & $1.00 \pm 0.00^{\circ}$ & $32.00 \pm 0.27 b c$ & $15.40 \pm 0.15^{b}$ & $13.68 \pm 0.17 \mathrm{~b}$ \\
\hline 9 & $5.62 \pm 0.01 \mathrm{~g}$ & $0.78 \pm 0.02 c$ & $52.76 \pm 0.21 \mathrm{c}$ & $9.00 \pm 0.00 \mathrm{e}$ & $25.55 \pm 0.21$ ğ & $13.56 \pm 0.15^{c}$ & $12.52 \pm 0.17 \mathrm{cc}$ \\
\hline 10 & $5.77 \pm 0.00 \varsigma$ & $0.42 \pm 0.00^{\mathrm{h}}$ & $51.91 \pm 0.28 \mathrm{ccd}$ & $3.50 \pm 0.00^{\mathrm{i}}$ & $31.49 \pm 0.49 \mathrm{bc}$ & $11.89 \pm 0.02^{\mathrm{e}}$ & $10.76 \pm 0.00 \mathrm{e}$ \\
\hline 11 & $5.71 \pm 0.00^{\mathrm{d}}$ & $0.47 \pm 0.02 \mathrm{~g}$ & $45.02 \pm 0.03 \mathrm{~g}$ & $2.00 \pm 0.00 \mathrm{~m}$ & $28.26 \pm 0.97^{\mathrm{f}}$ & $9.73 \pm 0.00^{\mathrm{h}}$ & $8.41 \pm 0.00^{\mathrm{h}}$ \\
\hline 12 & $5.67 \pm 0.00^{\mathrm{f}}$ & $0.56 \pm 0.00^{f}$ & $54.53 \pm 0.02^{\mathrm{c}}$ & $26.00 \pm 0.00^{a}$ & $21.83 \pm 0.30^{\mathrm{m}}$ & $3.48 \pm 0.03^{n}$ & $1.51 \pm 0.16^{\mathrm{k}}$ \\
\hline 13 & $5.83 \pm 0.00^{c}$ & $0.42 \pm 0.00^{\mathrm{h}}$ & $55.11 \pm 0.25^{b c}$ & $24.00 \pm 0.00 \varsigma$ & $23.04 \pm 0.071$ & $3.76 \pm 0.03^{\mathrm{m}}$ & $1.98 \pm 0.16^{\mathrm{i}}$ \\
\hline 14 & $5.36 \pm 0.00^{\circ}$ & $1.25 \pm 0.00^{a}$ & $46.96 \pm 0.06^{f}$ & $0.50 \pm 0.00^{\circ}$ & $32.46 \pm 0.38 \mathrm{~b}$ & $9.09 \pm 0.02^{1}$ & $7.93 \pm 0.16^{1}$ \\
\hline 15 & $5.68 \pm 0.01^{\mathrm{f}}$ & $0.43 \pm 0.02^{\mathrm{h}}$ & $54.48 \pm 0.20 c$ & $22.00 \pm 0.00 \mathrm{~d}$ & $24.49 \pm 0.04 \mathrm{ik}$ & $3.55 \pm 0.00^{\mathrm{n}}$ & $1.52 \pm 0.16^{\mathrm{k}}$ \\
\hline 16 & $5.62 \pm 0.00 \mathrm{~g}$ & $0.84 \pm 0.00 \mathrm{c}$ & $51.62 \pm 0.53 \mathrm{~d}$ & $6.00 \pm 0.00 \mathrm{~g}$ & $29.17 \pm 0.07$ ef & $12.97 \pm 0.21 \mathrm{c}$ & $12.64 \pm 0.00 \mathrm{c}$ \\
\hline 17 & $6.07 \pm 0.00^{a}$ & $0.21 \pm 0.00^{\mathrm{i}}$ & $55.49 \pm 0.25^{b}$ & $25.00 \pm 0.00^{\mathrm{b}}$ & $23.98 \pm 0.79 \mathrm{kl}$ & $4.16 \pm 0.04^{1}$ & $2.22 \pm 0.17^{\mathrm{i}}$ \\
\hline 18 & $5.84 \pm 0.00^{\mathrm{b}}$ & $0.31 \pm 0.00^{1}$ & $57.85 \pm 0.62^{\mathrm{a}}$ & $24.50 \pm 0.00^{c}$ & $24.82 \pm 0.16^{\mathrm{ik}}$ & $4.65 \pm 0.00^{\mathrm{k}}$ & $2.11 \pm 0.00^{\mathrm{i}}$ \\
\hline 19 & $5.56 \pm 0.00 \mathrm{~s}$ & $0.56 \pm 0.00^{\mathrm{f}}$ & $43.56 \pm 0.30 \breve{s}$ & $1.50 \pm 0.00^{\mathrm{n}}$ & $25.35 \pm 0.90^{\mathrm{ii}}$ & $12.09 \pm 0.02^{\mathrm{d}}$ & $11.39 \pm 0.00^{\mathrm{d}}$ \\
\hline 20 & $5.37 \pm 0.00^{\mathrm{n}}$ & $0.72 \pm 0.02^{\mathrm{d}}$ & $51.91 \pm 0.09$ çd & $3.25 \pm 0.35^{\mathrm{k}}$ & $35.54 \pm 0.53^{\mathrm{a}}$ & $12.48 \pm 0.01$ çd & $11.09 \pm 0.17^{\mathrm{ed}}$ \\
\hline En düşük/Min & $5.36 \pm 0.00$ & $0.21 \pm 0.00$ & $41.92 \pm 0.11$ & $0.50 \pm 0.00$ & $20.90 \pm 0.24$ & $3.48 \pm 0.03$ & $1.51 \pm 0.16$ \\
\hline En yülksek/Max & $6.07 \pm 0.00$ & $1.25 \pm 0.00$ & $57.85 \pm 0.62$ & $26.00 \pm 0.00$ & $35.54 \pm 0.53$ & $16.00 \pm 0.07$ & $15.43 \pm 0.00$ \\
\hline Ortalama./Mean & $5.59 \pm 0.19$ & $0.65 \pm 0.24$ & $50.73 \pm 4.54$ & $8.66 \pm 9.53$ & $27.71 \pm 4.01$ & $9.87 \pm 3.98$ & $8.61 \pm 4.43$ \\
\hline
\end{tabular}

KM: Kurumadde, Min.:Minimum, Mak.:Maksimum, Ort.:Ortalama.

DM:Dry matter, Min.:Minimum, Max.:Maximum, Ort::Mean.

Aynı sütunda farklı üstel harflerle gösterilen ortalama değerler birbirlerinden önemli derecede farklıdır $(P<0.01)$.

Mean values indicated by different exponential letters on the same column are significantly different from each other $(P<0.01)$.

Bayburt Civil peynir örneklerinde en düşük kül miktarı \%3.48, en yüksek kül miktan ise $\% 16.0$ olarak belirlenmiştir (Çizelge 1). İncelen örnekler arasında yağ oranında olduğu gibi kül oranları bakımından da büyük varyasyonlar vardır. $\mathrm{Bu}$ durum peynir örneklerinin içerdiği tuz miktarlarındaki farklılıktan kaynaklanmıştır. Bayburt Civil peynir örneklerinde tuz oranlar1 $\% 1.51$ ile $\% 15.43$ aralığında değişim göstermiş olup ortalama \%8.61 olarak tespit edilmiştir. Peynirde dayanıklillğ1 artırmak, asitliği ve olgunlaşmayı yönlendirmek, tat vermek ve peynir dokusunu düzeltmek amaciyla farklı yöntemlerle (salamura ve kuru tuzlama gibi) yapilabilen tuzlama işleminin, peynirin kurumadde ve kül miktarlarını büyük ölçüde etkilediği belirtilmiştir (Guinee ve Fox, 2017). Dikbaş vd. (2006), Çeçil peynir örneklerinde; kül oranlarının \%9.0-18.5 aralı̆̆ında değiştiğini ve ortalama $\% 12.66$ olduğunu; tuz miktarlarının ise \%5.49 ile \%15.09 aralığında değiştiğini ve ortalama \%11.7 olduğunu bildirmişlerdir. Yapılan başka bir çalışmada ise Çeçil peynir örneklerinde tuz ve kül oranları 
sirasiyla \%6.35-14.01 ve \%6.41-15.45 aralıklarında tespit edilmiştir (Bakırcı ve Andiç, 1999).

\section{Civil peynir örneklerinin mikrobiyolojik özellikleri}

Örneklerde TAMB sayılar1 5.94 log kob/g ile 8.83 $\log \mathrm{kob} / \mathrm{g}$ aralığında değişim göstermiştir (Çizelge 2). TAMB sayısının en yüksek tespit edildiği 13., 15. ve 17. örnekler tuz oranı en düşük 5 örnek arasında yer almaktadır. Tespit edilen değerler literatür bulguları ile benzerdir. Cambaztepe vd. (2009) ve Yildiz vd. (2010) Erzurum Civil peynir örneklerinde TAMB sayısının sirasiyla; 5.46-8.56 $\log \mathrm{kob} / \mathrm{g}, \quad 4.0-8.46 \log \mathrm{kob} / \mathrm{g}$ aralığında değiştiğini bildirmişlerdir. Yapılan bir başka çalışmada ise Çeçil peynir örneklerinde TAMB sayıs1 7.59-8.88 log kob/g olarak belirlenmiştir (Yangilar ve Kızılkaya, 2015). Peynir örneklerinin maya ve küf saylları $4.37 \log \mathrm{kob} / \mathrm{g}$ ile $10.14 \mathrm{log}$ $\mathrm{kob} / \mathrm{g}$ aralığında bulunmuştur. Örneklerde TAMB ve maya-küf sayılarının yüksek olması; üretimin ve depolamanın kontrolsüz şartlar altında yapıldığını ve muhafaza koşullarının kontaminasyona neden olduğunu göstermektedir. Cambaztepe vd. (2009) Civil peynir örneklerinde maya ve küf sayısını 3.84-5.29 log kob/g aralığında belirlemiştir. Yang1lar ve Kizılkaya (2015) ise Çeçil peynir örneklerinde maya ve küf sayisını 2.51-3.83 $\log \mathrm{kob} / \mathrm{g}$ arasinda bulmuşlardır. Koliform grubu bakteri ise sadece 5 örnekte,1.0-3.52 log kob/g aralı̆gında tespit edilmiştir. Cambaztepe vd. (2009) Civil peynir örneklerinde koliform grubu bakteri sayısını 2.94$6.77 \mathrm{log} \mathrm{kob} / \mathrm{g}$ aralığında, Yangılar ve Kızılkaya (2015) Çeçil peynir örneklerinde koliform grubu bakteri sayısını 3.23-3.86 log kob/g aralığında tespit etmiştir. Bu çalş̧mada, E. coli sadece 1 örnekte $(1 \mathrm{log} \mathrm{kob} / \mathrm{g})$ tespit edilirken, diğer 19 örnekte tespit edilebilir sınırnn altında kalmıştır. Örneklerin hiçbirinde $S$. aureus tespit edilmemiştir $(<1 \log \mathrm{kob} / \mathrm{g})$. Bu durum muhtemelen peynir örneklerinde tuz içeriğinin oldukça yüksek olmasından kaynaklı olabilir. Tuz, peynir mikrobiyotasının düzenlenmesi ve kontrolünde önemli bir role sahip olup peynirde patojenlerin gelişimini engellemektedir (Guinee ve Fox, 2017). Yangılar ve Kızılkaya (2015) Çeçil peynir örneklerinde $S$. aureus sayısını 2.2-4.1 log kob/g aralığında bulmuşlardır.

\section{Civil peynir örneklerinin biyokimyasal özellikleri}

Bayburt Civil peynir örneklerine ait bazı biyokimyasal analiz sonuçları Çizelge $3^{\prime} \mathrm{de}$ verilmiştir. Peynir örneklerinin; toplam azot, suda çözünen azot, TCA'da çözünen azot, olgunlaşma derecesi ve lipoliz özellikleri arasında önemli varyasyonlar tespit edilmiştir $(P<0.01)$. Peynir örneklerinde toplam azot oranlarının \%3.28$\% 5.57$ aralığında değiştiği belirlenmiştir. Benzer şekilde, Şengül vd (2006) Civil peynir örneklerinde toplam azot oranlarının \%3.01-5.57 aralığında değiştiğini rapor etmiştir. Yapılan başka bir çalısmada ise Civil peynir örneklerinde toplam azot oranlanı \%3.10-4.47 aralığında saptanmıştır (Cambaztepe vd., 2009).

Proteolizin oluşumunda başlıca; rennet, sütün doğal proteinazları, starter kültür proteinazları ve starter olmayan mikroorganizmaların ürettiği proteinazlar oldukça önemli bir yere sahiptir (Fox, 1989; Upadhyay vd., 2004; Diezhandino vd., 2015). Civil peynir üretiminde süte 1 sıl işlem uygulanmadığ1 ve starter kültür kullanılmadığ1 göz önünde bulundurulduğunda, proteoliz oluşumunun rennet, sütün doğal proteinazları ve mikrobiyal proteinazlar sayesinde gerçekleştiği söylenebilir.

Suda çözünen azot oranı, peynirde olgunlaşma derecesinin bir göstergesi olup, peyniraltı suyu proteinlerini, proteoz peptonları, kazeinin parçalanması sonucu oluşan küçük ve orta molekül ağırlıklı peptitlerin toplamı ifade edilmektedir (McSweeney ve Fox, 1997; Pavia vd., 2000). Peynir örneklerinde suda çözünen azot oranı \%0.19-\%3.33 aralığında saptanmıştır. Yüksek tuz konsantrasyonunun peynirde proteoliz üzerine negatif etkisi olduğu (Guinee ve Fox, 2017) göz önünde bulundurulduğunda, 6 . örnekte muhafaza şartları ve kontaminasyon düzeyine bağlı olarak tuzlama aşamasından önce yüksek oranda proteoliz gerçekleşmiş olduğu söylenebilir. Bakırcı ve Andiç (1999), Çeçil peynir örneklerinde suda çözünen azot oranların $1 \% 0.07$ 0.49 aralığında tespit etmişlerdir. Yıldız vd. (2010) ise Civil peynir örneklerinde suda çözünen azot oranlarının \%0.34-0.71 aralığında değiștiğini bildirmişlerdir. Elde edilen bulgular, Bakırcı ve 
Andiç (1999) ile Yıldız vd. (2010) tarafindan bildirilen değerlerden yüksek; Cakmakci vd. (2012)'nin küflü Civil peyniri örneklerinde tespit ettikleri suda çözünen azot değerlerinden (\%5.1727.20) oldukça düşüktür.

Çizelge 2 Bayburt Civil peynir örneklerine ait bazı mikrobiyolojik analiz sonuçları (log kob/g) Table 2 Some microbiological analysis results of Bayburt Civil cheese samples (log cfu $/ g)$

\begin{tabular}{|c|c|c|c|c|c|}
\hline $\begin{array}{l}\text { Örnekler } \\
\text { Samples }\end{array}$ & TAMB & $\begin{array}{l}\text { Maya ve Küf } \\
\text { Yeast and mold }\end{array}$ & $\begin{array}{c}\text { Koliform } \\
\text { Coliform }\end{array}$ & E. coli & S. aureus \\
\hline 1 & $7.50 \pm 0.25^{c}$ & $6.41 \pm 0.10^{\mathrm{d}}$ & $1.00 \pm 0.00^{c}$ & $1.00 \pm 0.00$ & $<1$ \\
\hline 2 & $5.94 \pm 0.17^{f}$ & $5.85 \pm 0.13^{\mathrm{e}}$ & $<1$ & $<1$ & $<1$ \\
\hline 3 & $6.31 \pm 0.18^{\mathrm{ef}}$ & $7.04 \pm 0.13 c$ & $<1$ & $<1$ & $<1$ \\
\hline 4 & $6.39 \pm 0.24^{e}$ & $4.85 \pm 0.24 \mathrm{~g}$ & $<1$ & $<1$ & $<1$ \\
\hline 5 & $7.02 \pm 0.18^{\mathrm{d}}$ & $4.47 \pm 0.20 \check{8}$ & $3.52 \pm 0.00^{a}$ & $<1$ & $<1$ \\
\hline 6 & $7.17 \pm 0.24 \varsigma^{\mathrm{d}}$ & $4.92 \pm 0.07 \mathrm{~g}$ & $<1$ & $<1$ & $<1$ \\
\hline 7 & $8.35 \pm 0.10^{\mathrm{bc}}$ & $4.97 \pm 0.27 \mathrm{~g}$ & $<1$ & $<1$ & $<1$ \\
\hline 8 & $6.02 \pm 0.08^{\mathrm{ef}}$ & $5.00 \pm 0.17 \mathrm{~g}$ & $<1$ & $<1$ & $<1$ \\
\hline 9 & $7.16 \pm 0.23 \mathrm{ccd}$ & $5.13 \pm 0.18^{\mathrm{fg}}$ & $<1$ & $<1$ & $<1$ \\
\hline 10 & $8.05 \pm 0.07^{c}$ & $7.09 \pm 0.13 c$ & $<1$ & $<1$ & $<1$ \\
\hline 11 & $6.29 \pm 0.07^{\mathrm{ef}}$ & $4.37 \pm 0.31 \check{\mathrm{s}}$ & $<1$ & $<1$ & $<1$ \\
\hline 12 & $6.05 \pm 0.07 \mathrm{ef}$ & $8.83 \pm 0.16^{\mathrm{b}}$ & $1.00 \pm 0.00^{c}$ & $<1$ & $<1$ \\
\hline 13 & $8.83 \pm 0.13^{a}$ & $9.16 \pm 0.11^{b}$ & $<1$ & $<1$ & $<1$ \\
\hline 14 & $6.94 \pm 0.08^{\mathrm{d}}$ & $10.14 \pm 0.20^{a}$ & $1.00 \pm 0.00^{c}$ & $<1$ & $<1$ \\
\hline 15 & $8.73 \pm 0.07 a$ & $9.09 \pm 0.14^{b}$ & $<1$ & $<1$ & $<1$ \\
\hline 16 & $7.03 \pm 0.07 \mathrm{~d}$ & $8.09 \pm 0.16^{c}$ & $<1$ & $<1$ & $<1$ \\
\hline 17 & $8.66 \pm 0.27 \mathrm{ab}$ & $8.96 \pm 0.11^{b}$ & $<1$ & $<1$ & $<1$ \\
\hline 18 & $6.35 \pm 0.20^{\mathrm{e}}$ & $6.66 \pm 0.17^{\mathrm{d}}$ & $<1$ & $<1$ & $<1$ \\
\hline 19 & $7.99 \pm 0.17 \mathrm{c}$ & $5.43 \pm 0.17 \mathrm{f}$ & $1.90 \pm 0.00^{\mathrm{b}}$ & $<1$ & $<1$ \\
\hline 20 & $6.81 \pm 0.10^{\mathrm{d}}$ & $5.48 \pm 0.17^{\mathrm{f}}$ & $<1$ & $<1$ & $<1$ \\
\hline En düşük/Min & $5.94 \pm 0.17$ & $4.37 \pm 0.31$ & $<1$ & $<1$ & $<1$ \\
\hline En yü̈ksek/Max & $8.83 \pm 0.13$ & $10.14 \pm 0.20$ & $3.52 \pm 0.00$ & $1.00 \pm 0.00$ & $<1$ \\
\hline
\end{tabular}

TAMB: Toplam Aerobik Mezofilik Bakteri Sayıs1.

TAMB: Total Number of Aerobic Mesophilic Bacteria, Min.:Minimum, Max::Maximum.

Aynı sütunda farklı üstel harflerle gösterilen ortalama değerler birbirlerinden önemli derecede farklıdır $(P<0.01)$. Mean values indicated by different exponential letters on the same column are significantly different from each other $(P<0.01)$.

$\mathrm{Bu}$ araştırmada TCA-SN oranları \%0.02 (4. örnek) ile \%0.69 (16. örnek) aralı̆̆ında değişim göstermiş olup, ortalama $\% 0.10$ olarak hesaplanmıştır (Çizelge 3). Benzer şekilde, Yıldız vd. (2010) Civil peynir örneklerinde TCA-SN oranlarını \%0.17-0.35 aralığında tespit etmişlerdir. Araştırmada tespit ettiğimiz TCA-SN oranlarının, Cambaztepe vd. (2009) tarafindan bildirilen (\%1.3-3.5) ve Cakmakcı vd. (2012) tarafindan belirlenen (\%4.90-14.93) değerlerden düşük olduğu görülmüştür. TCA-SN fraksiyonları, protein tabiatında olmayan azot olarak adlandirmaktadır. $\mathrm{Bu}$ protein fraksiyonu suda çözünen azotun önemli bir kısmını oluşturmakta olup, özellikle bakterilerin ve az da olsa rennetin proteolitik aktivitesi sonucu meydana gelmektedir (Christensen vd., 1991; McSweeney ve Fox, 1997). Bu bakımdan, Bayburt Civil peyniri örneklerinde, benzerlerine oranla düşük seviyede proteoliz gerçekleştiği söylenebilir.

Bayburt Civil peyniri örneklerinde, olgunlaşma derecesi \%4.38-\%71.20 aralığında değişmektedir. Suda çözünen azot üzerindeki etkili faktörler olgunlaşma derecesini belirlemektedir (Arslaner ve Bakırc1, 2016). İncelenen peynir örnekleri arasında olgunlaşma derecesi bakımından geniş bir varyasyon olmasi; peynir üretim tekniği, 
üretimde kullanılan rennetin kaynağ1, kalitesi ve miktarı, üretimde kullanılan sütün kimyasal kompozisyonu, peynir üretim şartları ve depolama koşulları gibi pek çok faktörden kaynaklanmış olabilir. $\mathrm{Bu}$ durum, peynir örneklerinin genel kimyasal kompozisyonlarında da görülmekte olup protein, yağ ve tuz oranlarındaki farklilıklardan da anlaşılmaktadır (Çizelge 1).

Çizelge 3 Bayburt Civil peynir örneklerine ait bazı biyokimyasal analiz sonuçları Table 3 Some biochemical analysis results of Bayburt Civil cheese samples

\begin{tabular}{|c|c|c|c|c|c|}
\hline $\begin{array}{l}\text { Örnekler } \\
\text { Samples }\end{array}$ & TN $(\%)$ & WSN (\%) & TCA-SN (\%) & $\begin{array}{l}\mathrm{OD}(\%) \\
\mathrm{RD}(\%)\end{array}$ & $\begin{array}{l}\text { Lipoliz (ADV) } \\
\text { Lipolysis (ADV) }\end{array}$ \\
\hline 1 & $4.75 \pm 0.05^{\text {ç }}$ & $1.14 \pm 0.02^{\mathrm{g}}$ & $0.07 \pm 0.02^{\text {cçde }}$ & $23.97 \pm 0.07 \mathrm{~g}$ & - \\
\hline 2 & $3.28 \pm 0.04 \mathrm{~m}$ & $1.24 \pm 0.01^{\mathrm{f}}$ & $0.07 \pm 0.02^{\text {cçde }}$ & $37.94 \pm 0.76^{\mathrm{d}}$ & $1.93 \pm 0.07 \check{g}$ \\
\hline 3 & $4.18 \pm 0.00 \mathrm{~g}$ & $0.41 \pm 0.01^{\mathrm{k}}$ & $0.07 \pm 0.00^{\text {ccde }}$ & $9.83 \pm 0.25^{\mathrm{k}}$ & $6.57 \pm 0.07 \mathrm{c}$ \\
\hline 4 & $4.89 \pm 0.00$ сç & $0.21 \pm 0.01^{\circ}$ & $0.02 \pm 0.00 \mathrm{~g}$ & $4.38 \pm 0.14^{\circ}$ & $2.52 \pm 0.00 \mathrm{~g}$ \\
\hline 5 & $4.08 \pm 0.12 \mathrm{gğ}$ & $1.85 \pm 0.04^{c}$ & $0.06 \pm 0.01$ ḑdef & $45.29 \pm 0.33^{b}$ & - \\
\hline 6 & $4.68 \pm 0.03 \mathrm{de}$ & $3.33 \pm 0.15^{\mathrm{a}}$ & $0.04 \pm 0.00^{\mathrm{efg}}$ & $71.20 \pm 0.16^{a}$ & $9.73 \pm 0.51^{\mathrm{c}}$ \\
\hline 7 & $4.91 \pm 0.05^{c}$ & $0.59 \pm 0.00^{\mathrm{i}}$ & $0.08 \pm 0.00$ cс & $11.92 \pm 0.18^{\mathrm{i}}$ & - \\
\hline 8 & $5.02 \pm 0.04^{c}$ & $2.27 \pm 0.02^{\mathrm{b}}$ & $0.07 \pm 0.00^{\text {ccdde }}$ & $45.20 \pm 0.11^{\mathrm{b}}$ & - \\
\hline 9 & $4.01 \pm 0.03 \mathrm{~g} \mathrm{ğ}_{1}$ & $1.60 \pm 0.00^{\mathrm{d}}$ & $0.08 \pm 0.00 \mathrm{ccsd}$ & $39.90 \pm 0.35$ & $3.47 \pm 0.09^{\mathrm{f}}$ \\
\hline 10 & $4.94 \pm 0.08^{c}$ & $1.83 \pm 0.01^{\mathrm{c}}$ & $0.07 \pm 0.00 \mathrm{ccsd}$ & $37.00 \pm 0.37 \mathrm{e}$ & - \\
\hline 11 & $4.43 \pm 0.15^{\mathrm{f}}$ & $0.70 \pm 0.00^{1}$ & $0.09 \pm 0.00^{c}$ & $15.91 \pm 0.46^{1}$ & - \\
\hline 12 & $3.42 \pm 0.05^{\mathrm{m}}$ & $0.28 \pm 0.00^{\mathrm{m}}$ & $0.04 \pm 0.00^{\mathrm{fg}}$ & $8.10 \pm 0.06^{1}$ & $11.07 \pm 0.33^{b}$ \\
\hline 13 & $3.61 \pm 0.01^{1}$ & $0.57 \pm 0.00^{\mathrm{i}}$ & $0.05 \pm 0.00$ def & $15.87 \pm 0.18^{1}$ & $5.65 \pm 0.24^{\mathrm{d}}$ \\
\hline 14 & $5.09 \pm 0.06^{\mathrm{b}}$ & $1.34 \pm 0.00^{\mathrm{e}}$ & $0.09 \pm 0.01^{\mathrm{c}}$ & $26.36 \pm 0.25^{\mathrm{f}}$ & - \\
\hline 15 & $3.84 \pm 0.01^{\mathrm{ik}}$ & $0.24 \pm 0.00^{\mathrm{n}}$ & $0.06 \pm 0.00$ cdef & $6.37 \pm 0.11^{\mathrm{m}}$ & $4.86 \pm 0.01^{\mathrm{e}}$ \\
\hline 16 & $4.57 \pm 0.01^{\mathrm{ef}}$ & $0.86 \pm 0.00 \mathrm{~g}$ & $0.69 \pm 0.00^{a}$ & $18.85 \pm 0.04 \check{s}$ & $12.23 \pm 0.21^{\mathrm{a}}$ \\
\hline 17 & $3.76 \pm 0.12^{\mathrm{kl}}$ & $0.38 \pm 0.00^{1}$ & $0.13 \pm 0.01^{b}$ & $10.04 \pm 0.33^{\mathrm{k}}$ & $6.34 \pm 0.05 c$ \\
\hline 18 & $3.89 \pm 0.03^{\text {tik }}$ & $0.19 \pm 0.00^{\circ}$ & $0.08 \pm 0.00^{\mathrm{cccd}}$ & $4.90 \pm 0.06^{\mathrm{no}}$ & $2.39 \pm 0.05^{\mathrm{g}}$ \\
\hline 19 & $3.97 \pm 0.14 \check{8}$ & $1.76 \pm 0.01 \mathrm{c}$ & $0.08 \pm 0.00$ cc & $44.25 \pm 0.41^{\mathrm{c}}$ & - \\
\hline 20 & $5.57 \pm 0.08^{\mathrm{a}}$ & $0.30 \pm 0.00^{\mathrm{m}}$ & $0.15 \pm 0.00^{\mathrm{b}}$ & $5.43 \pm 0.08^{n}$ & - \\
\hline En düşük/Min & $3.28 \pm 0.04$ & $0.19 \pm 0.00$ & $0.02 \pm 0.00$ & $4.38 \pm 0.14$ & $1.93 \pm 0.07$ \\
\hline En yükesek/Max & $5.57 \pm 0.08$ & $3.33 \pm 0.15$ & $0.69 \pm 0.00$ & $71.20 \pm 0.16$ & $12.23 \pm 0.21$ \\
\hline Ortalama/Mean & $4.34 \pm 0.62$ & $1.05 \pm 0.83$ & $0.10 \pm 0.04$ & $24.13 \pm 18.29$ & $6.07 \pm 3.58$ \\
\hline
\end{tabular}

TN: Toplam Azot, WSN: Suda Çözünen Azot, TCA-SN: Trikloroasetik Asitte Çözünen Azot, OD: Olgunlaşma Derecesi.

TN:Total Nitrogen, WSN: Water Soluble Nitrogen, TCA-SN: Tricloroacetic Acid Soluble Nitrogen, RD: Ripening Index, Min.:Minimum, Max.:Maximum.

Aynı sütunda farklı üstel harflerle gösterilen ortalama değerler birbirlerinden önemli derecede farklıdır $(P<0.01)$. Mean values indicated by different exponential letters on the same column are significantly different from each other $(P<0.01)$.

Peynirde; nem oran1, tuz oranı, $\mathrm{pH}$ ve depolama sicaklı̆̆ proteoliz üzerinde etkili faktörlerdir. Özellikle tuz konsantrasyonunun proteolizi güçlü şekilde etkilediği ve biyokimyasal olayları sınırlandırdığ1 bilinmektedir (Pavia vd., 2000; Guinee ve Fox, 2017). Araşturmada tespit ettiğimiz tuz değerleri (Çizelge 1) ile olgunlaşma dereceleri (Çizelge 3) karșılaștırıldığında, tuz oranı ve olgunlaşma derecesi arasında kesin bir negatif ilişki olduğu söylenememekle birlikte, tuz oranı yüksek bazı örneklerde proteolizin de yüksek bulunuşu muhtemelen tuzlama öncesi üretim şartları ile mikrobiyal faaliyete bağlı geçekleşen proteolizle alakalıdır. Şengül vd. (2006) Civil peynir örneklerinde olgunlaşma derecesini \% 4.25 8.80; Cambaztepe vd. (2009) \%2.34-8.43, Yildız vd. (2010) \%6.96-14.19 aralığında tespit etmişlerdir. 
Lipoliz değerleri ADV olarak Çizelge 3'de verilmiştir. Buna göre, peynir örneklerinde lipoliz değeri 1.93-12.23 ADV aralı̆̆ında değişim göstermiş olup, ortalama 6.07 ADV olarak bulunmuştur. Örneklerin 9 adedinde lipoliz tespit edilmemiştir. $\mathrm{Bu}$ durum, bu örneklerde yağ oranının $(\leq 3.50)$ oldukça düşük olması sonucunda analiz için yeterli miktarda yağ ekstrakte edilememesinden kaynaklanmıştır. Literatürde 1.5 veya daha yüksek ADV değerinin aşırı lipolizi gösterdiği bildirilmektedir (Park, 2001). Incelenen peynirlerde proteoliz nispeten zayıf olmasına rağmen, yukarıda verilen kritere göre, lipoliz tespit edilen 11 örnekte belirlenen ADV değerleri aşırı derecede lipolizin göstergesidir (Çizelge 3). Bu durum, peynir örneklerinin piyasada uzun süre, uygunsuz şartlarda kalmış olmasından kaynaklanabilir. Ayrıca peynir örneklerinin mikrobiyolojik kalitesinin yetersiz ve maya ve küf sayısının oldukça yüksek olması da lipoliz oranını artırmış olabilir. Peynir örneklerinin lipoliz değerleri (Çizelge 3) ile maya-küf sayıları (Çizelge 2) karşılaştırıldığında, genellikle lipoliz oranı yüksek olan örneklerde maya ve küf sayısının yüksek olduğu görülmüsstür. Yapilan çalışmalarda, çiğ sütten, starter kültür kullanılmadan üretilen peynirdeki lipolizin başlıca sorumlusu olarak; lipaz, çiğ süt mikrofloras1, starter olmayan laktik asit bakterileri belirtilmektedir (Collins vd., 2003). Bakırcı ve Andiç (1999), Çeçil peynir örneklerinde lipoliz değerlerinin 0.61-4.92 ADV aralığında değiştiğini ve ortalama 1.86 ADV olduğunu bildirmişlerdir.

\section{Bayburt Civil peyniri örneklerinin mineral kompozisyonu ve ağır metal içeriği}

Peynir örneklerine ait mineral ve ağır metal analiz sonuçları Çizelge 4'de verilmiştir. Peynir örneklerinin mineral kompozisyonu ve ağır metal içeriği üzerine örnek değişkeninin etkisi istatistiksel olarak önemli bulunmuştur $(P<0.01)$. Süt ürünlerinde (tereyağı hariç) ve özellikle peynirde en önemli minerallerden biri kalsiyumdur (Walther vd., 2008; Zamberlin vd., 2012). Çizelge 4'de görüldüğü gibi Civil peynir örneklerinde Ca miktarlar1 $772.89 \mathrm{mg} / \mathrm{kg}$ ile $2146.25 \mathrm{mg} / \mathrm{kg}$ aralığında tespit edilmiştir. Peynir örneklerinde en düşük $\mathrm{K}$ miktanı 8. örnekte
(755.38 mg/ kg) belirlenirken, en yüksek K miktar1 14. Örnekte $(2056.0 \mathrm{mg} / \mathrm{kg})$ saptanmıştır. Sütte en bol bulunan elementlerden biri de potasyum olup, peynirde konsantrasyonu oldukça yüksektir (Walther vd., 2008). Civil peynir örneklerinde P miktarlar1 $6403.39 \mathrm{mg} / \mathrm{kg}$ ile $11397.51 \mathrm{mg} / \mathrm{kg}$ aralığında belirlenmiştir. İncelenen peynir örneklerinde makro minerallerden $\mathrm{P}$ ve $\mathrm{Na}$ miktarının diğer minerallere kıyasla oldukça yüksek olduğu anlaşılmıştır. Peynir örneklerinde $\mathrm{Na}$ ve $\mathrm{Mg}$ miktarları s1rasiyla 14225.25-91688.18 $\mathrm{mg} / \mathrm{kg}, 332.56-1919.05 \mathrm{mg} / \mathrm{kg}$ aralığında değişim göstermiştir. Tespit edilen tuz miktarları (Çizelge 1) ile $\mathrm{Na}$ miktarları (Çizelge 4) karşılaştırıldığında, genellikle tuz oranı yüksek olan örneklerde $\mathrm{Na}$ miktarının yüksek olduğu görülmüştür. Mendil (2006), Çeçil peynir örneklerinde $\mathrm{Ca}, \mathrm{K}, \mathrm{Na}$ ve $\mathrm{Mg}$ miktarlarının sirasıyla; $3722 \mu \mathrm{g} / \mathrm{g}, 326 \mu \mathrm{g} / \mathrm{g}, 5405$ $\mu \mathrm{g} / \mathrm{g}$ ve $48 \mu \mathrm{g} / \mathrm{g}$ olduğunu bildirmiştir. Yapılan çalışmalarda, makro minerallerden $\mathrm{Ca}, \mathrm{K}, \mathrm{P}$ ve $\mathrm{Mg}$ için tavsiye edilen günlük alım miktarları sırasıyla; $800 \mathrm{mg} /$ gün, $2000 \mathrm{mg} /$ gün, $700 \mathrm{mg} /$ gün ve 375 $\mathrm{mg} /$ gün olarak rapor edilmiştir (Anonymous, 2017).

Örneklerde mikro minerallerden $\mathrm{Cu}, \mathrm{Fe}, \mathrm{Mn}, \mathrm{Zn}$, $\mathrm{Si}, \mathrm{Rb}, \mathrm{Sr}, \mathrm{Se}, \mathrm{Ba}$ ve In tespit edilmiş olup, miktarları $\mu \mathrm{g} / \mathrm{kg}$ kuru ağırlık cinsinden Çizelge 4'de verilmiştir. Demir ( $\mathrm{Fe})$ ve bakır $(\mathrm{Cu})$ insan sağlığ1 için önemli olmakla birlikte yüksek konsantrasyonlarda alımı canlı hücrelerde zehirlenmeye neden olabilmektedir (Ayar vd., 2009). Peynir örneklerinde $\mathrm{Cu}$ ve Fe miktarlar1 sirasiyla $0.00-891.60 \mu \mathrm{g} / \mathrm{kg}, 0.00-31113.0 \mu \mathrm{g} / \mathrm{kg}$ aralığında tespit edilmiştir. $\mathrm{Cu}$ için günlük güvenli ve yeterli alım oranı $1.5-3.0 \mathrm{mg}$, eşik değeri ise vücut ağırlı̆̆1 başına $0.05-0.5 \mathrm{mg} / \mathrm{kg}$ olarak bildirilmiştir $\mathrm{Fe}$ için önerilen günlük alım miktarı 10-15 mg'dır (Nabrzyski, 2007). Manganez (Mn), tüm canlı organizmalar için en önemli eser mineraller arasında olup, çeşitli enzim reaksiyonları, protein metabolizması ve kemik oluşumunda önemli bir role sahiptir (Zafar ve Fatima, 2018). Mn için günlük güvenli ve yeterli alım oranı 2.0-3.0 mg olarak belirlenmiştir (Nabrzyski, 2007). İncelenen peynir örneklerinde; en düşük Mn miktarı $34.15 \mu \mathrm{g} / \mathrm{kg}$ ile 3. örnekte, en yüksek $\mathrm{Mn}$ miktan $1077.14 \mu \mathrm{g} / \mathrm{kg}$ ile 11 . örnekte tespit edilmiştir. Birçok enzimin önemli 
bileşenlerinden olan çinko (Zn) insan fizyolojisi üzerinde pek çok fonksiyona sahip esansiyel bir mikro mineraldir (Gharibzahedi ve Jafari, 2017). Peynir örneklerinin Zn açısından iyi bir kaynak olduğu anlaşılmaktadır (Çizelge 4). Buna göre, örneklerde Zn miktar1 49949.43-94558.05 $\mathrm{gg} / \mathrm{kg}$ aralı̆̆ında değişim göstermiştir. Zn için tavsiye edilen günlük alım miktan 12-15 mg/gün, eşik değeri ise vücut ağırlı̆̆ başına $0.3-1.0 \mathrm{mg} / \mathrm{kg}$ olarak bildirilmiştir (Nabrzyski, 2007). Örneklerde $\mathrm{Si}, \mathrm{Rb}, \mathrm{Sr}, \mathrm{Se}, \mathrm{Ba}$ ve In miktarlarn ise sirasiyla; 0.00 $132243.58 \mu \mathrm{g} / \mathrm{kg}, \quad 0.00-821.73 \mu \mathrm{g} / \mathrm{kg}, 4810.50-$ $36405.24 \mu \mathrm{g} / \mathrm{kg}, \quad 0.00-723.57 \mu \mathrm{g} / \mathrm{kg}, \quad 1226.05-$ $4951.59 \mu \mathrm{g} / \mathrm{kg}$ ve $0.00-7040.92 \mu \mathrm{g} / \mathrm{kg}$ aralığinda tespit edilmiştir. Mendil (2006) de Çeçil peynir örneklerinde $\mathrm{Cu}, \mathrm{Fe}, \mathrm{Mn}$ ve $\mathrm{Zn}$ miktarlarının sirasiyla; $0.22 \mu \mathrm{g} / \mathrm{g}, 9.3 \mu \mathrm{g} / \mathrm{g}, 0.97 \mu \mathrm{g} / \mathrm{g}$ ve 13.2 $\mu \mathrm{g} / \mathrm{g}$ olduğunu bildirmiştir.

Çizelge 4 Bayburt Civil peynir örneklerine ait mineral ve ağır metal analiz sonuçları Table 4Mineral and heavy metal analysis results of Bayburt Civil cheese samples

\begin{tabular}{|c|c|c|c|c|c|}
\hline \multirow{2}{*}{$\begin{array}{l}\text { Örnekler } \\
\text { Samples }\end{array}$} & \multicolumn{5}{|c|}{$\begin{array}{l}\text { Makro mineraller (mg/kg kuru ağırlık) } \\
\text { Macro minerals (mg/kg dry weight) }\end{array}$} \\
\hline & $\mathrm{Ca}$ & $\mathrm{K}$ & $\mathrm{P}$ & $\mathrm{Na}$ & $\mathrm{Mg}$ \\
\hline 1 & $1604.38 \pm 11.62^{c}$ & $1978.70 \pm 51.08^{\mathrm{ab}}$ & $9477.00 \pm 14.45^{\mathrm{c}}$ & $53124.23 \pm 163.58 \breve{s}$ & $489.89 \pm 12.20^{\mathrm{de}}$ \\
\hline 2 & $1023.25 \pm 2.59$ ğ & $1818.24 \pm 27.90^{c}$ & $6791.31 \pm 12.21^{1}$ & $88298.73 \pm 147.52^{b}$ & $487.81 \pm 11.79 \mathrm{de}$ \\
\hline 3 & $772.89 \pm 4.24^{\mathrm{h}}$ & $1891.07 \pm 31.96^{\mathrm{bc}}$ & $6403.39 \pm 13.04^{\mathrm{i}}$ & $70391.99 \pm 46.74 \mathrm{e}$ & $332.56 \pm 2.15^{1}$ \\
\hline 4 & $2146.25 \pm 11.21^{\mathrm{a}}$ & $1373.44 \pm 33.59 \mathrm{e}$ & $10625.68 \pm 54.43^{\mathrm{b}}$ & $68424.46 \pm 79.61^{\mathrm{f}}$ & $1919.05 \pm 22.53^{\mathrm{a}}$ \\
\hline 5 & $1144.58 \pm 57.46 \mathrm{fg}$ & $1572.66 \pm 45.75 \mathrm{çd}$ & $8249.41 \pm 58.59^{f}$ & $91688.18 \pm 46.01^{\mathrm{a}}$ & $502.66 \pm 2.38^{d}$ \\
\hline 6 & $1008.58 \pm 22.54 \breve{g}$ & $1094.67 \pm 12.54^{\mathrm{f}}$ & $6963.81 \pm 52.23^{1}$ & $86495.97 \pm 69.62^{c}$ & $438.23 \pm 17.48^{\text {fgğ }}$ \\
\hline 7 & $1184.27 \pm 26.69^{\mathrm{ef}}$ & $1338.00 \pm 35.58^{\mathrm{e}}$ & $7986.98 \pm 64.66$ 㴦 & $76588.52 \pm 54.45^{\mathrm{d}}$ & $1065.11 \pm 75.42^{\mathrm{b}}$ \\
\hline 8 & $1369.85 \pm 38.57^{d}$ & $755.38 \pm 9.05^{\breve{s}}$ & $8150.64 \pm 61.57^{\mathrm{fg}}$ & $86072.07 \pm 120.49^{c}$ & $417.71 \pm 6.97 \mathrm{gğh}$ \\
\hline 9 & $1693.60 \pm 50.57 \mathrm{c}$ & $955.36 \pm 15.15 \mathrm{~g}$ & $9037.06 \pm 56.74 \mathrm{~d}$ & $76807.38 \pm 57.06^{\mathrm{d}}$ & $591.41 \pm 4.88$ \\
\hline 10 & $1066.66 \pm 21.30 \mathrm{gğ}$ & $1181.15 \pm 38.37^{f}$ & $6885.33 \pm 59.62^{1}$ & $76711.65 \pm 80.33^{\mathrm{d}}$ & $450.26 \pm 4.79^{\text {efg }}$ \\
\hline 11 & $1818.89 \pm 11.09^{c}$ & $1997.11 \pm 72.87 \mathrm{a}$ & $10001.32 \pm 136.51^{\mathrm{c}}$ & $69626.93 \pm 86.07 \mathrm{e}$ & $422.03 \pm 9.43$ ğğ \\
\hline 12 & $1268.18 \pm 76.21^{\mathrm{e}}$ & $1598.57 \pm 50.40$ çd & $8157.14 \pm 65.83^{f g}$ & $14225.25 \pm 127.39^{\mathrm{i}}$ & $335.00 \pm 3.42^{1}$ \\
\hline 13 & $1602.25 \pm 92.83$ & $1577.25 \pm 93.64$ çd & $9362.41 \pm 79.28^{c}$ & $15296.39 \pm 138.66^{1}$ & $389.08 \pm 7.13^{\mathrm{h}}$ \\
\hline 14 & $1079.56 \pm 95.04 \mathrm{gğ}$ & $2056.00 \pm 52.36^{a}$ & $8691.68 \pm 14.81^{\mathrm{e}}$ & $63559.19 \pm 338.07 \mathrm{~g}$ & $458.46 \pm 2.59 \mathrm{defg}$ \\
\hline 15 & $1643.28 \pm 31.11 \mathrm{c}$ & $1814.47 \pm 61.97 \mathrm{c}$ & $10597.16 \pm 139.26^{b}$ & $15264.84 \pm 51.43^{1}$ & 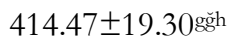 \\
\hline 16 & $1261.49 \pm 66.84^{\mathrm{e}}$ & $1165.56 \pm 25.74^{\mathrm{f}}$ & $7695.04 \pm 79.51^{\mathrm{h}}$ & $68497.40 \pm 49.15^{\mathrm{f}}$ & $340.93 \pm 6.241$ \\
\hline 17 & $1612.90 \pm 13.76 \mathrm{c}$ & $1287.66 \pm 3.10^{\mathrm{e}}$ & $9892.14 \pm 127.42^{c}$ & $14484.64 \pm 19.11^{\mathrm{ii}}$ & $394.84 \pm 9.83^{\mathrm{gh}}$ \\
\hline 18 & $2001.65 \pm 15.02^{b}$ & $1494.32 \pm 52.86^{\mathrm{d}}$ & $11397.51 \pm 196.79^{a}$ & $17923.54 \pm 36.18^{\mathrm{h}}$ & $473.42 \pm 5.88^{\mathrm{def}}$ \\
\hline 19 & $1219.11 \pm 2.69^{\mathrm{ef}}$ & $1313.17 \pm 69.82^{\mathrm{e}}$ & $7840.72 \pm 70.14$ ğh & $78658.47 \pm 417.19$ c & $724.05 \pm 11.09 \mathrm{c}$ \\
\hline 20 & $999.54 \pm 16.48 \check{s}$ & $1648.66 \pm 48.01 \mathrm{c}$ & $7659.89 \pm 58.27 \mathrm{~h}$ & $62727.82 \pm 188.64 \mathrm{~g}$ & $390.21 \pm 6.39 \mathrm{~h}$ \\
\hline En düşük/ Min & $772.89 \pm 4.24$ & $755.38 \pm 9.05$ & $6403.39 \pm 13.04$ & $14225.25 \pm 127.39$ & $332.56 \pm 2.15$ \\
\hline En yüksek/Max & $2146.25 \pm 11.21$ & $2056.00 \pm 52.36$ & $11397.51 \pm 196.79$ & $91688.18 \pm 46.01$ & $1919.05 \pm 22.53$ \\
\hline
\end{tabular}

Min.:Minimum, Max::Maximum

Aynı sütunda farklı üstel harflerle gösterilen ortalama değerler önemli derecede birbirlerinden farklıdır $(P<0.01)$. Mean values indicated by different exponential letters on the same column are significantly different from each other $(P<0.01)$. 
Çizelge 4 Bayburt Civil peynir örneklerine ait mineral ve ağır metal analiz sonuçları (devam) Table 4 Mineral and heavy metal analysis results of Bayburt Civil cheese samples(continued)

\begin{tabular}{|c|c|c|c|c|c|}
\hline \multirow{2}{*}{$\begin{array}{l}\text { Örnekler } \\
\text { Samples }\end{array}$} & \multicolumn{5}{|c|}{$\begin{array}{l}\text { Mikro mineraller ( } \mu \mathrm{g} / \mathrm{kg} \text { kuru ağırllik) } \\
\text { Micro minerals ( } \mu \mathrm{g} / \mathrm{kg} d r y \text { weight) }\end{array}$} \\
\hline & $\mathrm{Cu}$ & $\mathrm{Fe}$ & $\mathrm{Mn}$ & $\mathrm{Zn}$ & $\mathrm{Si}$ \\
\hline 1 & $891.60 \pm 3.01^{a}$ & $5656.67 \pm 62.82 \check{g}$ & $351.49 \pm 11.31^{\mathrm{f}}$ & $92310.62 \pm 53.17 \mathrm{c}$ & $66436.33 \pm 46.40 \mathrm{e}$ \\
\hline 2 & $222.82 \pm 8.06^{\mathrm{h}}$ & $3991.71 \pm 75.29 \mathrm{~h}$ & $206.60 \pm 2.45^{\mathrm{h}}$ & $63722.90 \pm 128.88^{\mathrm{k}}$ & $79431.05 \pm 27.22^{\mathrm{d}}$ \\
\hline 3 & $98.68 \pm 1.01^{1}$ & $11694.42 \pm 116.21^{c}$ & $34.15 \pm 0.42^{\mathrm{n}}$ & $66339.21 \pm 57.18^{i}$ & $41160.64 \pm 21.35^{1}$ \\
\hline 4 & $97.19 \pm 2.58^{1}$ & $11461.47 \pm 82.02 c$ & $446.21 \pm 3.58 \mathrm{e}$ & $87672.58 \pm 130.9 c$ & $64225.76 \pm 95.32^{\mathrm{f}}$ \\
\hline 5 & TE & $5689.18 \pm 14.55 \mathrm{s̆}$ & $109.35 \pm 7.89 \mathrm{~m}$ & $84561.61 \pm 177.53^{\mathrm{e}}$ & $95877.61 \pm 81.51^{b}$ \\
\hline 6 & $3.80 \pm 0.20^{\mathrm{i}}$ & $10925.33 \pm 39.80 \mathrm{~d}$ & $152.43 \pm 9.49^{\mathrm{ik}}$ & $78192.91 \pm 52.56$ ğ & $63297.04 \pm 39.47 \mathrm{~g}$ \\
\hline 7 & $696.18 \pm 8.43^{c}$ & $8890.72 \pm 43.84 \mathrm{~g}$ & $484.29 \pm 15.72^{\mathrm{d}}$ & $94558.05 \pm 80.33^{a}$ & $93730.43 \pm 63.48^{c}$ \\
\hline 8 & $351.21 \pm 10.13^{\mathrm{f}}$ & $10434.32 \pm 44.89 \mathrm{e}$ & $194.72 \pm 7.05^{\mathrm{h} 1}$ & $67173.88 \pm 27.83^{1}$ & $92898.18 \pm 27.86 \mathrm{c}$ \\
\hline 9 & $354.74 \pm 11.37^{f}$ & $31113.0 \pm 86.56^{\mathrm{a}}$ & $789.03 \pm 11.04 c$ & $92784.59 \pm 92.81^{b}$ & $132243.58 \pm 88.68^{a}$ \\
\hline 10 & $405.82 \pm 7.87 \mathrm{e}$ & $11260.31 \pm 54.35 \mathrm{c}$ & $249.21 \pm 15.24 \check{s}$ & $53180.69 \pm 96.51^{\mathrm{n}}$ & $49588.74 \pm 82.46 \check{g}$ \\
\hline 11 & $264.61 \pm 9.89 \check{8}$ & TE & $1077.14 \pm 38.41 \mathrm{a}$ & $84306.00 \pm 7.67 \mathrm{e}$ & TE \\
\hline 12 & $345.41 \pm 4.24^{\mathrm{f}}$ & TE & $875.63 \pm 15.34^{c}$ & $49949.43 \pm 84.82^{\circ}$ & 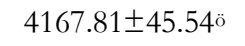 \\
\hline 13 & $315.16 \pm 5.12 \mathrm{~g}$ & TE & $141.84 \pm 11.64^{\mathrm{kl}}$ & $59199.08 \pm 78.43^{m}$ & $19642.33 \pm 26.45^{\mathrm{m}}$ \\
\hline 14 & $706.01 \pm 10.31^{c}$ & $9306.03 \pm 9.04^{\mathrm{f}}$ & $186.26 \pm 5.36^{\mathrm{h}}$ & $81243.59 \pm 92.56^{\mathrm{f}}$ & $24890.61 \pm 17.56^{1}$ \\
\hline 15 & $295.31 \pm 4.71 \mathrm{~g}$ & $64.83 \pm 1.20^{\mathrm{k}}$ & $195.33 \pm 10.60^{\mathrm{hr}}$ & $64013.14 \pm 31.01^{\mathrm{k}}$ & $15641.33 \pm 80.34^{\circ}$ \\
\hline 16 & $555.22 \pm 7.03 \mathrm{c}$ & $1343.78 \pm 48.08^{1}$ & $173.21 \pm 1.51^{1 \mathrm{i}}$ & $85960.02 \pm 71.56^{\mathrm{d}}$ & $39025.14 \pm 39.20^{\mathrm{i}}$ \\
\hline 17 & $345.58 \pm 51.52^{\mathrm{f}}$ & $1039.08 \pm 24.47^{\mathrm{i}}$ & $271.56 \pm 8.041 \mathrm{~g}$ & $59200.25 \pm 38.13 \mathrm{~m}$ & TE \\
\hline 18 & $480.61 \pm 12.20 \mathrm{~d}$ & $\mathrm{TE}$ & $124.51 \pm 7.91 \mathrm{~lm}$ & $63140.57 \pm 8.91^{1}$ & $29321.77 \pm 23.49 \mathrm{k}$ \\
\hline 19 & $685.59 \pm 20.19 \mathrm{c}$ & $21038.84 \pm 89.34 b$ & $915.06 \pm 24.52^{\mathrm{b}}$ & $78857.44 \pm 22.95 \mathrm{~g}$ & $47582.94 \pm 31.26^{\mathrm{h}}$ \\
\hline 20 & $815.48 \pm 28.54 \mathrm{~b}$ & $3819.42 \pm 21.45^{\mathrm{h}}$ & $497.37 \pm 16.55^{\mathrm{d}}$ & $77271.23 \pm 67.51^{\mathrm{h}}$ & $17988.20 \pm 26.94 \mathrm{n}$ \\
\hline En düsük/Min & TE & $\mathrm{TE}$ & $34.15 \pm 0.42$ & $49949.43 \pm 84.82$ & TE \\
\hline En yükssek./Max & $891.60 \pm 3.01$ & $31113.0 \pm 86.56$ & $1077.14 \pm 38.41$ & $94558.05 \pm 80.33$ & $132243.58 \pm 88.68$ \\
\hline \multirow{2}{*}{$\begin{array}{l}\text { Örnekler } \\
\text { Samples }\end{array}$} & \multicolumn{5}{|c|}{$\begin{array}{l}\text { Mikro mineraller ( } \mu \mathrm{g} / \mathrm{kg} \text { kuru ağırlik) } \\
\text { Micro minerals }(\mu \mathrm{g} / \mathrm{kg} d r y \text { weight) }\end{array}$} \\
\hline & $\mathrm{Rb}$ & $\mathrm{Sr}$ & Se & $\mathrm{Ba}$ & In \\
\hline$\overline{1}$ & $735.51 \pm 1.92^{c}$ & $9004.92 \pm 10.37 \mathrm{~h}$ & TE & $2937.0 \pm 32.13^{\mathrm{d}}$ & TE \\
\hline 2 & $634.28 \pm 7.78^{\mathrm{d}}$ & $7787.68 \pm 26.06^{\mathrm{ik}}$ & TE & $2589.34 \pm 15.46^{\mathrm{f}}$ & $1274.71 \pm 2.42 \mathrm{~g}$ \\
\hline 3 & TE & $7512.83 \pm 41.58^{\mathrm{k}}$ & TE & $1315.51 \pm 23.94 k$ & $\mathrm{TE}$ \\
\hline 4 & $580.50 \pm 2.86 \mathrm{e}$ & $36405.24 \pm 280.34 \mathrm{a}$ & TE & $4951.59 \pm 37.55^{\mathrm{a}}$ & $293.31 \pm 1.15^{\mathrm{h}}$ \\
\hline 5 & $278.41 \pm 41.68 \mathrm{~g}$ & $8464.13 \pm 87.041$ & TE & $1943.97 \pm 42.03^{\mathrm{h}}$ & TE \\
\hline 6 & $0.00 \pm 0.00^{\mathrm{h}}$ & $12697.85 \pm 141.94 c$ & TE & $1753.46 \pm 23.21^{1}$ & $3329.82 \pm 16.02^{\mathrm{f}}$ \\
\hline 7 & $240.00 \pm 1.92 \check{g}$ & $20263.13 \pm 134.85^{b}$ & TE & $3411.14 \pm 3.35^{c}$ & $5395.70 \pm 114.47 \mathrm{c}$ \\
\hline 8 & TE & $10693.13 \pm 35.26^{\mathrm{e}}$ & TE & $2288.58 \pm 14.27 \mathrm{~g}$ & $5391.29 \pm 116.74 \mathrm{c}$ \\
\hline 9 & TE & $9329.19 \pm 6.24 g_{h}$ & TE & $2889.47 \pm 7.45^{\mathrm{d}}$ & $4394.13 \pm 122.58^{d}$ \\
\hline 10 & $642.53 \pm 3.89 \mathrm{~d}$ & $10288.42 \pm 133.18^{\mathrm{ef}}$ & $723.57 \pm 7.00^{a}$ & $2104.73 \pm 7.91 \breve{g}$ & $7040.92 \pm 10.30^{a}$ \\
\hline 11 & $677.79 \pm 42.21 \mathrm{c}$ & $11129.42 \pm 81.47 \mathrm{~d}$ & $290.41 \pm 6.64 c$ & $4400.10 \pm 1.44 \mathrm{~b}$ & $6534.94 \pm 19.04 \mathrm{~b}$ \\
\hline 12 & $770.74 \pm 2.16^{\mathrm{b}}$ & $8137.53 \pm 35.75^{\mathrm{i}}$ & TE & $2638.33 \pm 2.25^{f}$ & TE \\
\hline 13 & $731.93 \pm 2.05^{c}$ & $9666.61 \pm 19.90 \mathrm{ğg}$ & $56.16 \pm 0.17 \mathrm{~d}$ & $2629.68 \pm 41.10^{\mathrm{f}}$ & TE \\
\hline 14 & $796.33 \pm 2.06^{b}$ & $6889.61 \pm 36.02^{1}$ & $52.88 \pm 1.13 \mathrm{~d}$ & $1226.05 \pm 2.32^{1}$ & TE \\
\hline 15 & $821.73 \pm 10.63^{a}$ & $9282.49 \pm 67.75$ ğh & $35.44 \pm 0.42^{\mathrm{e}}$ & $3160.50 \pm 56.51 \mathrm{c}$ & TE \\
\hline 16 & $314.72 \pm 3.17 \mathrm{f}$ & $8531.38 \pm 7.20^{1}$ & $192.56 \pm 0.68$ & $1405.79 \pm 27.06^{\mathrm{i}}$ & $977.95 \pm 11.43 \check{s}$ \\
\hline 17 & $708.68 \pm 2.97 \mathrm{c}$ & $8533.97 \pm 44.11^{1}$ & TE & $2741.24 \pm 36.56^{\mathrm{e}}$ & TE \\
\hline 18 & $673.83 \pm 6.25$ & $10068.44 \pm 26.76 \mathrm{fg}$ & TE & $2889.47 \pm 16.33^{\mathrm{d}}$ & $6062.86 \pm 57.35^{\mathrm{c}}$ \\
\hline 19 & $591.59 \pm 5.91 \mathrm{e}$ & $13847.95 \pm 65.01 \mathrm{c}$ & $312.17 \pm 24.58^{b}$ & $2786.0 \pm 16.48 \mathrm{e}$ & TE \\
\hline 20 & $304.14 \pm 1.93 \mathrm{fg}$ & $4810.50 \pm 10.79 \mathrm{~m}$ & $14.11 \pm 0.18^{f}$ & $2319.95 \pm 82.67 \mathrm{~g}$ & $3515.37 \pm 38.76 \mathrm{e}$ \\
\hline En düsü̈k/Min & TE & $4810.50 \pm 10.79$ & TE & $1226.05 \pm 2.32$ & TE \\
\hline En yüksek. /Max & $821.73 \pm 10.63$ & $36405.24 \pm 280.34$ & $723.57 \pm 7.00$ & $4951.59 \pm 37.55$ & $7040.92 \pm 10.30$ \\
\hline
\end{tabular}

TE: Tespit edilmedi, TE: Not found, Min.: Minimum, Max.: Maximum

Aynı sütunda farklı üstel harflerle gösterilen ortalama değerler birbirlerinden önemli derecede farklıdır $(P<0.01)$.

Mean values indicated by different exponential letters on the same column are significantly different from each other $(P<0.01)$ 
Çizelge 4 Bayburt Civil peynir örneklerine ait mineral ve ağır metal analiz sonuçları (devam) Table 4 Mineral and heavy metal analysis results of Bayburt Civil cheese samples(continued)

\begin{tabular}{|c|c|c|c|c|c|c|c|}
\hline \multirow{2}{*}{$\begin{array}{l}\text { Örnekler } \\
\text { Samples }\end{array}$} & \multicolumn{7}{|c|}{$\begin{array}{c}\text { Ağ1r metaller ( } \mu \mathrm{g} / \mathrm{kg} \text { kuru ağırlık) } \\
\text { Heavy metals ( } \mu \mathrm{g} / \mathrm{kg} d r y \text { weight) }\end{array}$} \\
\hline & As & $\mathrm{Al}$ & $\mathrm{Ag}$ & $\mathrm{Cd}$ & $\mathrm{Cr}$ & $\mathrm{Co}$ & $\mathrm{Pb}$ \\
\hline 1 & TE & TE & $\mathrm{TE}$ & $979.69 \pm 1.41^{\mathrm{a}}$ & $187.52 \pm 1.95 c$ & $2.72 \pm 0.06^{\mathrm{d}}$ & $\mathrm{TE}$ \\
\hline 2 & TE & TE & TE & TE & TE & TE & TE \\
\hline 3 & TE & TE & TE & TE & $72.98 \pm 2.12 c$ & TE & TE \\
\hline 4 & $\mathrm{TE}$ & TE & TE & TE & $543.14 \pm 5.66^{\mathrm{b}}$ & TE & TE \\
\hline 5 & TE & $4017.02 \pm 122.41^{1}$ & TE & TE & TE & TE & TE \\
\hline 6 & $\mathrm{TE}$ & $19418.77 \pm 86.17 \mathrm{~b}$ & TE & TE & $9.24 \pm 0.17 \mathrm{~d}$ & TE & TE \\
\hline 7 & $\mathrm{TE}$ & $18191.01 \pm 98.92^{c}$ & TE & TE & TE & TE & TE \\
\hline 8 & $\mathrm{TE}$ & $10333.41 \pm 144.07 \mathrm{e}$ & TE & TE & TE & TE & TE \\
\hline 9 & $\mathrm{TE}$ & $13248.38 \pm 149.48$ c & TE & TE & $1203.44 \pm 62.83^{\mathrm{a}}$ & TE & $\mathrm{TE}$ \\
\hline 10 & TE & $4970.59 \pm 40.12^{\mathrm{h}}$ & $376.63 \pm 2.80^{a}$ & TE & TE & TE & TE \\
\hline 11 & TE & $9612.26 \pm 122.49^{f}$ & $180.68 \pm 1.88^{\mathrm{b}}$ & $139.63 \pm 0.56^{\mathrm{e}}$ & TE & TE & TE \\
\hline 12 & $\mathrm{TE}$ & $9762.42 \pm 84.23^{\mathrm{f}}$ & $103.37 \pm 1.13^{\mathrm{e}}$ & $132.31 \pm 0.51^{\mathrm{f}}$ & TE & $10.12 \pm 0.37 \mathrm{~b}$ & TE \\
\hline 13 & $\mathrm{TE}$ & $8779.92 \pm 40.11 \mathrm{~g}$ & $75.17 \pm 0.17 \mathrm{~g}$ & $143.71 \pm 0.47 \mathrm{~d}$ & TE & $3.73 \pm 0.35 c$ & TE \\
\hline 14 & TE & $6192.99 \pm 29.66^{\breve{g}}$ & TE & $203.62 \pm 1.34^{c}$ & TE & TE & TE \\
\hline 15 & $\mathrm{TE}$ & $2433.14 \pm 90.16^{\mathrm{i}}$ & $19.31 \pm 0.42^{\mathrm{h}}$ & $\mathrm{TE}$ & TE & TE & TE \\
\hline 16 & $\mathrm{TE}$ & $5842.75 \pm 65.01 \check{\mathrm{s}}$ & $124.75 \pm 1.40 c$ & $201.40 \pm 0.35 \mathrm{c}$ & TE & TE & TE \\
\hline 17 & $\mathrm{TE}$ & $4166.96 \pm 75.08^{1}$ & $113.88 \pm 1.61^{d}$ & $109.30 \pm 0.81 \mathrm{~g}$ & $189.94 \pm 10.55^{c}$ & TE & $14.12 \pm 0.18^{c}$ \\
\hline 18 & $\mathrm{TE}$ & $11294.73 \pm 63.52^{\mathrm{d}}$ & $62.48 \pm 0.55^{\breve{g}}$ & $370.39 \pm 0.41^{b}$ & TE & TE & TE \\
\hline 19 & $\mathrm{TE}$ & $35487.79 \pm 45.51^{\mathrm{a}}$ & $133.18 \pm 2.42^{c}$ & TE & $168.77 \pm 6.07 \mathrm{c}$ & $28.64 \pm 0.35^{a}$ & $181.81 \pm 5.19^{\mathrm{a}}$ \\
\hline 20 & $\mathrm{TE}$ & $0.41 \pm 0.04^{\circ}$ & $97.27 \pm 0.27^{\mathrm{f}}$ & $1.96 \pm 0.03 \breve{s}$ & $0.7 \pm 0.1^{\mathrm{d}}$ & $6.39 \pm 0.11^{\mathrm{c}}$ & $66.55 \pm 0.75^{\mathrm{b}}$ \\
\hline En düsük/Min & TE & TE & TE & TE & TE & TE & $\mathrm{TE}$ \\
\hline En yüksek/Max & $\mathrm{TE}$ & $35487.79 \pm 45.51$ & $376.63 \pm 2.80$ & $979.69 \pm 1.41$ & $1203.44 \pm 62.83$ & $28.64 \pm 0.35$ & $181.81 \pm 5.19$ \\
\hline
\end{tabular}

TE: Tespit edilmedi, TE: Not found, Min.:Minimum, Max.:Maximum

Aynı sütunda farklı üstel harflerle gösterilen ortalama değerler birbirlerinden önemli derecede farklıdır $(P<0.01)$. Mean values indicated by different exponential letters on the same column are significantly different from each other $(P<0.01)$

Süt ve süt ürünleri çeşitli minerallerin kaynağını oluşturmakla birlikte; yüksek endüstriyel, kentsel ve tarımsal emisyonların neden olduğu çevre kirliliğinin artması nedeniyle çeşitli konsantrasyonlarda kirletici maddeler (ağır metaller gibi) içerebilmektedir (Capcarova vd., 2017). Peynirin ağır metal içeriği; peynir çeşidi, coğrafi alan, üretim uygulamalarının özellikleri ve işlem sırasında ekipmandan kaynaklanan kirlenme gibi faktörler nedeniyle değişkendir (Mendil, 2006; Serencam vd., 2018). Bayburt Civil peynir örneklerinde ağır metallerden $\mathrm{As}, \mathrm{Al}, \mathrm{Ag}, \mathrm{Cd}, \mathrm{Cr}$, Co ve $\mathrm{Pb}$ varlığ araştırlmış, analiz sonuçları $\mu \mathrm{g} / \mathrm{kg}$ kuru ağırlı cinsinden Çizelge 4'de verilmiştir. Peynir örneklerinin hiçbirinde As tespit edilmemiştir. Civil peynir örneklerinde Al, $\mathrm{Ag}, \mathrm{Cd}, \mathrm{Cr}$, Co ve $\mathrm{Pb}$ miktarları sirasiyla $0.00-$ $35487.79 \mu \mathrm{g} / \mathrm{kg}, 0.00-376.63 \mu \mathrm{g} / \mathrm{kg}, 0.00-979.69$ $\mu \mathrm{g} / \mathrm{kg}, 0.00-1203.44 \mu \mathrm{g} / \mathrm{kg}, 0.00-28.64 \mu \mathrm{g} / \mathrm{kg}$ ve $0.00-181.81 \mu \mathrm{g} / \mathrm{kg}$ aralı̆̆ında değişim göstermiştir.
Gıda Katk1 Maddeleri Uzmanlar Komitesi (JECFA) tarafindan yetişkinler için Al'un haftalık tolere edilebilir alım oranı $2 \mathrm{mg} / \mathrm{kg}$ vücut ağırlı̆̆1 olarak bildirilmiștir (JECFA, 2009). As, Cd, Cr, Ni ve $\mathrm{Pb}$ gibi metaller insan için potansiyel bir kanser riski oluşturacak şekilde sınıflandırlmıştır. İnsülin hormonu üretiminde ve yağ metabolizmasında görev aldığı da bilinen $\mathrm{Cr}$ için güvenli ve yeterli alım oranı yetişkinler için $0.05-0.20 \mathrm{mg} / \mathrm{gün}, \mathrm{Ni}$ için 0.05-0.3 mg/gün olarak bildirilmiştir (Nabrzyski, 2007). Cd için tolere edilebilir haftalık alım miktarını $0.007 \mathrm{mg} / \mathrm{kg}$ vücut ağıllığ, $\mathrm{Pb}$ için $0.025 \mathrm{mg} / \mathrm{kg}$ vücut ağırlığ1 olarak bildirilmiştir (JECFA, 2009). JECFA (2009) ve Türk Gida Kodeksi (Anonymous, 2011) tarafindan yayınlanan rapor ve tebliğlerde $\mathrm{Ag}$, $\mathrm{Cr}$ ve Co ile ilgili bir sınırlandırmaya rastlanmamıştır. Mendil (2006) Çeçil peynir örneklerinde $0.14 \mu \mathrm{g} / \mathrm{kg} \mathrm{Pb}$ ve $0.04 \mu \mathrm{g} / \mathrm{kg} \mathrm{Cr}$ tespit etmiștir. Yapılan bașka bir çalışmada ise Civil peynir örneklerinin hiçbirinde $\mathrm{Cr}, \mathrm{Cd}, \mathrm{Hg}$ ve As tespit edilmemiş olup, 
örneklerde $\mathrm{Pb}$ miktarlar1 $0.02-0.05 \quad \mathrm{mg} / \mathrm{kg}$ aralığında saptanmıştır (Serencam vd., 2018).

Araştırma sonuçlarına göre, ağır metal analizi yapilan Bayburt Civil peynir örneklerinde, tespit edilen $\mathrm{Al}, \mathrm{Pb}$ ve $\mathrm{Cd}$ değerlerinin JECFA tarafından bildirilen limitlerin altında olduğu görülmüştür. Bu çalışma kapsamında incelenen Bayburt Civil peyniri örneklerinin ağır metal içeriği bakımından herhangi bir sağlık riski taşımadığı sonucuna varılmıştır.

\section{SONUÇ ve ÖNERLER}

$\mathrm{Bu}$ araştırmada elde edilen bulguların, Bayburt Civil peynirinin Coğrafi İşaret olarak tescillenmesi durumunda gerek duyulacak veri tabanın oluşturulmasına ve ürün standardizasyonuna katk1 sağlayacağ1 düşünülmektedir. Bileşim özellikleri bakımından örnekler arasında önemli varyasyonların bulunması, bu yöresel peynirin hammadde, üretim, ambalajlama ve depolamasında bir standardın bulunmadığını ortaya koymaktadır. Bayburt Civil peyniri, üretiminde kullanılan sütün yağ oranı bakımından standardize edilmemesi, çoğunlukla yağlı süt kullanılması ve benzerlerine göre daha ince teller halinde işlenmesi ile farklılık göstermektedir. Özellikle peynirlerin yağ oranlarındaki farklılık bu peynir çeşidinde bir sınıflandırmayı gerekli kılmaktadır. Toplam aerobik mezofilik bakteri ve maya-küf sayılarının oldukça yüksek çıkmış olması; peynire işlenen çiğ sütün hijyenik kalitesinin düşük olduğunu, üretimin kontrollü şartlarda yapılmadığını, peynirin üretimden sonraki aşamalarında (tuzlama, paketleme, depolama ve sevkiyat gibi) hijyenik kurallara uyulmadığından ciddi bir kontaminasyona maruz kaldığını göstermektedir. Bayburt Civil peynirinin mikrobiyolojik açıdan güvenli şekilde tüketilmesi için zorunlu depolama süresi araştırmalarla belirlenmelidir. Sonuç olarak, yöre halkının beslenmesinde önemli bir yere sahip olan Bayburt Civil peynirinin orijinal özelliklerinin korunarak ürün kalitesinin geliştirilmesi ve standardizasyonu halk sağlığ1 ve bölgenin sosyo-ekonomik kalkınması açısından önem arz etmektedir. Bu amaçla, kontrollü şartlar altında üretilen yöresel Bayburt Civil peynir örneklerinde araştırma sayisinin artırlmasina, üreticinin bilinçlendirilmesine ve denetimin artırılmasına ihtiyaç vardır.

\section{KAYNAKLAR}

Anonymous (2017). Türk gida Kodeksi Gıda Etiketleme ve Tüketicileri Bilgilendirme Yönetmeliği. Gıda, Tarım ve Hayvancıllk Bakanlı̆̆1. 26 Ocak 2017 tarih ve 29960 Say1l (Mükerrer) Resmî gazete, Ankara.

Anonymous (2011). Türk Gıda Kodeksi. Bulaşanlar Yönetmeliği. Gida, Tarım ve Hayvancilık Bakanlığı. 29 Aralık 2011 tarih ve 28157 Sayıl1 (3. Mükerrer) Resmi Gazete, Ankara.

Arslaner, A., Bakırcı, İ. (2016). Farklı ambalaj materyallerinde olgunlaştırılan tulum peynirlerinde proteoliz. Uluslararasi Erzincan Sempozyumu, Cilt 3, 28 Eylül-1 Ekim 2016, Erzincan, Türkiye, 815-824 s.

Arslaner, A., Salik, M. A. (2017). Some physicochemical and microbiological characteristics of the Civil cheese put up for sale in Bayburt market. II. International Conference on Advanced Engineering Technologies, 21-23 September 2017, Bayburt, Türkiye.

Ataro, A., McCrindle, R. I., Botha, B. M., McCrindle, C. M. E., Ndibewu, P. P. (2008). Quantification of trace elements in raw cow's milk by inductively coupled plasma mass spectrometry (ICP-MS). Food Chem, 111(1): 243-248. Doi: 10.1016/j.foodchem.2008.03.056.

Ayar, A., Sert, D., Akin, N. (2009). The trace metal levels in milk and dairy products consumed in Middle Anatolia-Turkey. Environ Monit Assess, 152(1-4): 1-12. Doi: 10.1007/s10661-008-0291-9.

Bakırcı, İ., Andiç, S. (1999). Muş-Bulanık yöresinde üretilen Çeçil peyniri üzerinde bir araştırma. YYÜ Vet Fak Derg, 10(1-2): 67-71.

Cambaztepe, F., Çakmakçı, S., Dağdemir, E. (2009). Effect of some technological parameters on microbiological, chemical and sensory qualities of Civil cheese during ripening. Int J Dairy Technol, 62(4): 541-548. Doi: 10.1111/j.14710307.2009.00536.x.

Cantürk, A., Çakmakç1, S. (2019). Erzurum çevresindeki peynir işletmelerinde kullanılan 
peynir mayalarının mikrobiyolojik, duyusal ve teknolojik özellikleri. Akademik Gida, 17(1): 3037. Doi: 10.24323/akademik-gida.544064.

Capcarova, M., Harangozo, L., Toth, T., Schwarczova, L., Bobkova, A., Stawarz, R., Guidi A, Massanyi, P. (2017). Detection of selected trace elements in yogurt components. J Environ Sci Health Part B, 52(12): 1-6. Doi: 10.1080/03601234.2017.1359029.

Christensen, T. M. I. E., Bech, A. M., Werner, H. (1991). Methods for Crude Fractionation (extraction and precipitation) of Nitrogen Components in Cheese, IDF Bulletin 261. Brussels: International Dairy Federation.

Collins, Y. F., McSweeney, P. L. H., Wilkinson, M. G. (2003). Lipolysis and free fatty acid catabolism in cheese: A review of current knowledge. Int Dairy J, 13(11): 841-866. Doi: 10.1016/S0958-6946(03)00109-2.

Çakmakçı, S., Gundogdu E., Hayaloglu A. A., Dagdemir, E., Gurses, M., Cetin, B., TahmasKahyaoglu D. (2012a). Chemical and microbiological status and volatile profiles of mouldy Civil cheese, a Turkish mould-ripened variety. Int J Food Sci Tech, 47: 2405-2412. Doi:10.1111/j.1365-2621.2012.03116.x.

Çakmakçı, S., Çetin, B., Gürses, M., Dağdemir, E., Hayaloğlu, A.A. (2012b). Morphological, molecular and mycotoxigenic identification of dominant filamentous fungi from Moldy Civil cheese. J Food Prot, 75(11): 2045-2049.

Çakmakçı, S., Hayaloğlu, A. A., Dağdemir, E., Cetin, B., Gurses, M., Tahmas-Kahyaoğlu, D. (2014). Effects of Penicillium roqueforti and whey cheese on gross composition, microbiology and proteolysis of mould-ripened Civil cheese during ripening. Int J Dairy Technol, 67(4): 594-603. Doi: 10.1111/1471-0307.12156.

Çakmakçı S., Gürses, M., Hayaloglu, A.A., Cetin, B., Şekerci, P., Dagdemir, E. (2015). Mycotoxin production capability of Penicillium roqueforti strains isolated from mould-ripened traditional Turkish Civil cheese. Food Addit Contam: Part A, 32(2): 245-249. Doi: 10.1080/19440049.2014.997808.
Diezhandino, I., Fernández, D., González, L., McSweeney, P. L. H., Fresno, J. M. (2015). Microbiological, physicochemical and proteolytic changes in a Spanish blue cheese during ripening (Valdeón cheese). Food Chem, 168: 134-141. Doi: 10.1016/j.foodchem.2014.07.039.

Dikbaş, N., Şengül, M., Ertugay, M. F. (2006). Erzurum'da üretilen Çeçil peynirinin bazı fiziksel ve kimyasal özelliklerinin belirlenmesi. Türkiye 9 . Gıda Kongresi. 24-26 Mayıs 2006. Bolu, Türkiye, 161-164 s.

Fox, P. F, Uniacke-Lowe, T., McSweeney, P. L. H., O'Mahony, J. A. (2015). Chemistry and Biochemistry of Cheese. Chapter 12. In: Dairy Chemistry and Biochemistry. Springer International Publishing. Switzerland. pp. 499546.

Fox, P. F. (1989). Proyeolysis during cheese manufacture and ripening. J. Dairy Sci., 72(6): 1379-1400. Doi: $\quad 10.3168 /$ jds.S00220302(89)79246-8.

Gharibzahedi, S. M. T., Jafari, S. M. (2017). The importance of minerals in human nutrition: bioavailability, food fortification, processing effects and nanoencapsulation. Trends Food Sci Tech, 62: 119-132. Doi: 10.1016/j.tifs.2017.02.017.

Guinee, T. P., Fox, P. F. (2017). Salt in Cheese: Physical, Chemical and Biological Aspects, Chapter 13, In Cheese: Chemistry, Physics and Microbiology. http://dx.doi.org/10.1016/B9780-12-417012-4.00013-2, pp. 317-375.

Gürkan., H., Yilmaztekin., M., Cakmakci, S., Hayaoglu, A. (2018). Volatile compounds and biogenic amines during the ripening of moldripened Civil cheese manufactured using three different strains of Penicillium roqueforti. J Food Saf, 38 (6): 1-14. Doi: 10.1111/jfs.12568.

Halkman, K. (2005). Gida Mikrobiyolojisi Uygulamaları. Ankara: Başak Matbaacılık.

Harrigan, W. F. (1998). Laboratory Methods in Food Microbiology. Academic Press, San Diego, USA.

IDF (1991). International Dairy Federation Standard Method 50B: Milk and Milk Products. 
Routine methods for determination of free fatty acids in milk. IDF, Brussels, Belgium.

IDF (1993). International Dairy Federation Standard Method 20B: Milk. Determination of Nitrogen content. IDF, Brussels, Belgium.

JECFA (2009). Evaluations of the Joint FAO/WHO Expert Committee on Food Additives, http://apps.who.int/food-additivescontaminants-jecfa-database/search.aspx.

(ErişimTarihi: 28.01.2020).

Kuchroo, C. N., Fox, P. F. (1982). Soluble nitrogen in cheese: Comparison of extraction procedures. Milchwissenschaft, 37: 331-335. ISSN : 0026-3788.

Kurt, A., Çakmakçı, S., Çağlar, A. (2012). Süt ve Mamülleri Muayene ve Analiz Metotları Rehberi(10. Basım). Erzurum: Atatürk Üniversitesi Yayınlar1 No:252/D, 254 s.

McSweeney, P. L. H., Fox, P. F. (1997). Chemical methods for the characterization of proteolysis in cheese during ripening. Lait, 77(1): 41-76. Doi: 10.1051/lait:199713.

Mendil, D. (2006). Mineral and trace metal levels in some cheese collected from Turkey. Food Chem, 96 (4): 532-537. Doi: 10.1016/j.foodchem.2005.03.006.

Nabrzyski, M. (2007). Functional Role of Some Minerals in Foods. In: Szefer P, Nriagu JO. Mineral Components in Foods. Boca Raton: CRC Press, pp: 123-127. ISBN-13: 978-0-8493-2234-1.

Park, Y. W. (2001). Proteolysis and lipolysis of goat milk cheese. J Dairy Sci, 84 (E. Suppl.): E84E92. Doi: 10.3168/jds.S0022-0302(01)70202-0.

Pavia, M., Trujillo, A. J, Guamis, B., Ferragut, V. (2000). Proteolysis in monchego-type cheese salted by brine vacuum imprengnation. J Dairy Sci, 83(7): 1441-1447. Doi: 10.3168/jds.S00220302(00)75014-4.

Pichhardt, K. (2004). Gida Mikrobiyolojisi (Gida Endüstrisi için Temel Esaslar ve Uygulamalar). Literatür Yayıncilık, İstanbul.

Serencam, H., Arslaner, A., Köse, M. (2018). Civil peynirde ağır metal kontaminasyon kaynağı ve düzeyinin belirlenmesi üzerine bir araştırma. Engineering Sciences, (NWSAENS), 13 (1): 21-26. Doi:10.12739/NWSA.2018.13.1.1A0397.

Şengül, M., Gürses, M., Dervisoglu, M., Yazıc1, F. (2006). A survey on the some chemical and biochemical properties of Civil cheese, a traditional Turkish cheese. Int J Food Prop, 9: 791801. Doi: 10.1080/10942910600596415.

TÜRK PATENT (2009). Türk Patent ve Marka Kurumu Coğrafi İşaret Tescil Belgesi. Erzurum Civil Peyniri, Tescil No: 116. https://www.ci.gov.tr/cografi-

isaretler/detay/37987 (Erişim Tarihi:18.08.2019).

Upadhyay, V. K., McSweeney, P. L. H., Magboul, A. A. A., Fox, P. H. (2004). Proteoysis in Cheese During Ripening, Cheese: Chemistry, Physics and Microbiology, Third Edition-Volume 1: General Aspects ISBN: 0-1226-3652-XSet ISBN: 0-12263651-1, 391-433.

Walther, B., Schmid, A., Sieber, R., Wehrmüller, K. (2008). Cheese in nutrition and health. Dairy Sci Technol, 88(4-5): 389-405. Doi: 10.1051/dst:2008012.

Yangilar, F., Kızlkaya, P. Ç. (2015). Ardahan'ın aromatik Çeçil peynirlerinin mikrobiyolojik ve kimyasal özelliklerinin belirlenmesi. Bitlis Eren Üniversitesi Fen Bilimleri Dergisi, 4(2): 122-130. Doi:10.17798/beufen.04274.

Yıldız, F., Yetişemiyen, A., Şenel, E., DurluÖzkaya, F., Öztekin, Ş., Şanl1, E. (2010). Some properties of Civil cheese: A type of traditional Turkish cheese. Int J Dairy Technol, 63(4): $\quad$ 575-580. Doi:10.1111/j.14710307.2010.00612.x.

Zafar, M. H., Fatima, M. (2018). Efficiency comparison of organic and inorganic minerals in poultry nutrition: A review. PSM Vet Res, 3(2): 5359. ISSN: 2518-2714.

Zamberlin, S., Antunac, N., Havranek, J., Samaržija, D. (2012). Mineral elements in milk and dairy products. Mljekarstvo, 62(2): 111-125. 